\title{
Beyond belief: Strategic taboos and organizational identity in strategic agenda setting
}

Strategic Organization 2014, Vol. 12(4) 244-273 (C) The Author(s) 2014

Reprints and permissions: sagepub.co.uk/journalsPermissions.nav DOI: $10.1177 / 1476 \mid 27014544092$ soq.sagepub.com

\section{Christina Hoon}

Gottfried Wilhelm Leibniz Universität Hannover, Germany

\section{Claus D Jacobs}

Berne University of Applied Sciences and University of St. Gallen, Switzerland

\begin{abstract}
A comprehensive strategic agenda matters for fundamental strategic change. Our study seeks to explore and theorize how organizational identity beliefs influence the judgment of strategic actors when setting an organization's strategic agenda. We offer the notion of "strategic taboo" as those strategic options initially disqualified and deemed inconsistent with the organizational identity beliefs of strategic actors. Our study is concerned with how strategic actors confront strategic taboos in the process of setting an organization's strategic agenda. Based on a revelatory inductive case study, we find that strategic actors engage in assessing the concordance of the strategic taboos with organizational identity beliefs and, more specifically, that they focus on key identity elements (philosophy; priorities; practices) when doing so. We develop a typology of three reinterpretation practices that are each concerned with a key identity element. While contextualizing assesses the potential concordance of a strategic taboo with an organization's overall philosophy and purpose, instrumentalizing assesses such concordance with respect to what actors deem an organization's priorities to be. Finally, normalizing explores concordance with respect to compatibility and fit with the organization's practices. We suggest that assessing concordance of a strategic taboo with identity elements consists in reinterpreting collective identity beliefs in ways that make them consistent with what organizational actors deem the right course of action. This article discusses the implications for theory and research on strategic agenda setting, strategic change, a practicebased perspective on strategy, and on organizational identity.
\end{abstract}

\section{Keywords}

Organizational identity beliefs, strategic agenda setting, strategic options, strategic taboo

\section{Corresponding author:}

Christina Hoon, Institute of Human Resource Management, Faculty of Economics and Management, Gottfried Wilhelm Leibniz Universität Hannover, Königsworther Platz I, D 30167 Hannover, Germany.

Email: hoon@pua.uni-hannover.de 
"Whenever a taboo is broken, something good happens, something vitalizing."

Henry Miller

\section{Introduction}

Fundamental strategic change is vital for an organization's survival and prosperity (e.g. Agarwal and Helfat, 2009; Barr et al., 1992; Floyd and Lane, 2000). Thus, putting the "right" strategic items on the organization's strategic agenda is central for successful strategic change (Dutton, 1986, 1997; Dutton and Penner, 1993; Thomas and McDaniel, 1990). Often, however, strategic actors struggle with identifying and selecting these items due to certain biased judgments (Bansal, 2003; Sharma, 2000; Thomas and McDaniel, 1990). While the cognitive and the emotional realm have received considerable attention in agenda setting scholarship (Bansal, 2003; Dutton and Jackson, 1987; Huy, 2011; Plambeck and Weber, 2009), the normative realm has been less examined to date.

In this article, we offer the notion of "strategic taboo" in order to conceptualize those strategic options that are deemed off-limits or out of bounds in relation to the collective organizational identity beliefs of strategic actors. In turn, such disqualified options are likely to be ignored or deselected from the initial pool of strategic options. Understanding how strategic actors confront strategic taboos is important since strategic taboos might be viable strategic options that - if ignored or neglected - might lead to a foreshortened, ineffective strategic agenda and as a consequence, hamper much needed fundamental strategic change (Levinthal and March, 1993; Tripsas and Gavetti, 2000).

A strategic agenda entails the set of selected and prioritized strategic options guiding subsequent implementation of strategic change (Dutton, 1986). As omitting strategically relevant options results in an agenda staying fairly constant or being filled with similar issues over time (Dutton and Penner, 1993), a sufficiently diverse and varied pool of initial strategic options is crucial. However, the identification, interpretation and selection of strategic options hinges on judgments of strategic actors which may be biased by past experience, over-rationalization (Dutton and Jackson, 1987; Milliken, 1990; Plambeck and Weber, 2009; Sonenshein, 2007) or emotional commitments (Dutton and Dukerich, 1991; Huy, 2011). Such biased judgments seem to result from strategic actors' evaluation of a strategic option against a specific frame of reference in terms of their norms, values, and beliefs - embodied in an organization's identity beliefs (Clark et al., 2010; Gioia et al., 2000; Hamilton and Gioia, 2010). Strategic actors' judgment might lead to neglecting or ignoring potentially viable strategic options because these might not comply with the organization's normative frame of reference; in other words, they may be what we call "strategic taboos." Our article explores how strategic actors confront strategic taboos in the process of agenda setting.

The purpose of our study is to offer a typology of reinterpretation practices employed by organizational actors when confronting strategic taboos. The typology is developed through a revelatory inductive case study of the 4-year strategic change process of the Lutheran Church in Germany (LCG). We examined how two strategic options that were initially deemed off-limits, namely, "centralizing administrative power at the level of the local priest" as well as "defining leadership roles and responsibilities for priests," were critically explored and evaluated in a strategy process. The participatory, consultative, and evaluative quality of such processes is especially common in professional bureaucracies or pluralistic settings that are shaped by the divergent goals and interests of different groups of strategic actors (Denis et al., 2007; Jarzabkowski and Fenton, 2006).

The central argument we develop based on our investigation is that when confronting strategic taboos, strategic actors assess concordance of a strategic taboo with organizational identity beliefs. This assessment consists in a reinterpretation of similar identity elements mobilized by proponents and opponents of such concordance. Strategic actors assess the taboos in light of the organizational 
identity beliefs of strategic actors - employing three practices of reinterpretation, namely, contextualizing, instrumentalizing, and normalizing. Thus, assessing concordance of a strategic taboo with identity beliefs consists of reinterpreting identity elements in ways that make them consistent with what an organizational actor deems the right course of action.

Our article stands to make several contributions to strategic agenda setting scholarship, strategic change, a practice-based perspective on strategy as well as to an understanding of the linkages between strategy and identity in general. First, we develop and define the concept of strategic taboos to denote strategic options initially deemed off-limits in relation to the collective organizational identity beliefs of strategic actors. Second, we demonstrate the relevance of strategic taboos for strategic agenda setting both conceptually and empirically. Third and most importantly, we develop a typology of practices of reinterpretation to conceptualize the efforts organizational actors engage in when confronting strategic taboos within the overall process of strategic agenda setting.

We suggest that the concept of strategic taboos provides a useful analytical focus and terminology to understand how organizational identity beliefs influence the judgment of strategic actors. Furthermore, by illustrating the effect of strategic taboos on strategic agenda setting, our study sensitizes scholars not only to the cognitive or emotional realm, but also to the normative realm that informs strategic actors' judgment. Finally, our typology provides a valuable analytical framework for considering how an organization and its strategic actors go about confronting strategic taboos in their agenda setting.

The remainder of the article is organized as follows. First, we summarize the literature on strategic agenda setting within the broader field of strategic issue interpretation and note a need for detailing out how organizational identity beliefs influence the judgment of strategic actors. To conceptualize strategic options that are potentially neglected in the strategic agenda, we develop the concept of "strategic taboos" which drives our empirical investigation of how strategic actors confront strategic taboos within agenda setting. After outlining our method, we present our field analysis of the strategic agenda setting at LCG. Based on the latter, we develop a typology of reinterpretation practices employed by strategic actors when facing strategic taboos more generally. The article concludes by discussing the implications of our study for strategic agenda setting and strategic change as well as for the bodies of literature on a practice-based perspective to the linkages between strategy and identity.

\section{The role of strategic taboos in strategic agenda setting}

\section{Organizational identity beliefs and strategic actors' judgment of strategic options}

Given volatile environments and changing stakeholder expectations, fundamental strategic change is vital for an organization's survival and prosperity (e.g. Greenwood and Hinings, 1996); yet, not all organizations manage to create the "right" strategic agenda to achieve this (e.g. Hamel and Prahalad, 1994; Markides, 1997). Thus, fundamental strategic change relies on a sufficiently diverse and varied pool of initial strategic options that are then to be explored and evaluated for their potential inclusion in the organization's strategic agenda (Greenwood and Hinings, 1996; Tushman and Romanelli, 1985). In turn, a narrow, limited pool of strategic options risk creating a foreshortened strategic agenda, constraining fundamental strategic change (Levinthal and March, 1993; Tripsas and Gavetti, 2000).

The genesis of this initial pool of strategic options crucially relies on the judgment by strategic actors that in turn will lead to a strategic agenda for the organization (e.g. Ashford et al., 1998; Dutton and Ashford, 1993; Dutton and Dukerich, 1991). How strategic actors identify and diagnose strategic options and how selected options make it onto the organization's strategic agenda has been at the core of the literature on strategic issue interpretation in general and on strategic 
agenda setting in particular (Bansal, 2003; Dutton, 1986; Dutton and Jackson, 1987; Dutton and Penner, 1993; Sharma, 2000; Thomas and McDaniel, 1990). A strategic agenda involves the set of selected and prioritized strategic options that in turn guides the implementation of strategic change (Dutton, 1986, 1997).

Setting a strategic agenda entails the process through which a subset of potential strategic options is collectively identified, judged, and selected as a set of viable strategic agenda items (Dutton, 1997; Dutton and Dukerich, 1991). Most broadly, strategic options have been suggested as those developments, events, or actions perceived as potentially having a significant impact on the present or future strategic orientation of an organization (Dutton, 1997). Identifying and selecting viable strategic options is considered necessary for building a broad and comprehensive strategic agenda, and subsequently, for fundamental strategic change (Dutton, 1986; Dutton and Jackson, 1987; Thomas et al., 1993). However, the risk of a foreshortened strategic agenda lies in biased judgments by strategic actors.

Scholars have pointed to different aspects influencing judgments of strategic actors (e.g. Ashford et al., 1998; Bansal, 2003; Dutton and Dukerich, 1991; Huy, 2011; Plambeck and Weber, 2009; Sonenshein, 2007). Such bias has been typically associated with implicit, historical commitment of strategic actors (Hodgkinson and Wright, 2002; Schwenk, 1988) or their emotional commitment (Dutton et al., 2002; Huy, 2011).

Thus, when making sense of strategic issues, strategic actors deploy a variety of heuristics and frames that are often underpinned by a rational, utilitarian calculus (Sonenshein, 2007). Such biased judgments lead strategic actors to selectively attend to, prioritize, or rationalize certain strategic options over others (Dutton and Jackson, 1987; Sonenshein et al., 2014). A potentially viable strategic option might be ignored or deselected from the initial pool of strategic options due to strategic actors' judgment that the respective option might not be in line with the organization's history and purpose.

Such judgment seems to result from strategic actors' evaluation of a strategic option against a specific frame of reference in terms of their norms, values, and beliefs-embodied in an organization's identity (Dutton and Penner, 1993). Reframing Albert and Whetten's (1985) “classic" organizational identity characteristics of centrality, endurance, and distinctiveness from a social constructionist perspective, Gioia et al. (2000: 64) define organizational identity as the "collective understandings of the features presumed to be central and relatively permanent, and that distinguish the organization from other configuration."

Organizational identity as a broad "umbrella construct" has been suggested to consist of two complementary aspects, namely, organizational identity claims and organizational identity beliefs (Ravasi and Schultz, 2006: 435-6). Whereas the former is grounded in an institutionalist view and is concerned with who members claim they are as an organization to others (e.g. Livengood and Reger, 2010), organizational identity beliefs operate from a social constructionist view and concerned with who members believe they are as an organization (e.g. Gioia et al., 2000, 2010; Gioia and Patvardhan, 2012). The latter construct had already been suggested by Dutton and Penner (1993: 96) as the pivotal perceptual and evaluative "filter" in strategic agenda setting and its relevance has been re-emphasized more recently by Ravasi and Schultz (2006) and by Ravasi and Phillips (2011). Equally, Hamilton and Gioia (2010) highlight the hermeneutic capacity of organizational identity beliefs in terms of a deep level frame of interpretation and understanding in organizations. Thus, when evaluating a strategic option, organizational members juxtapose it with organizational identity beliefs to assess whether an option resonates sufficiently with collective understandings of what organizational actors deem central, relatively permanent, and distinctive about an organization for inclusion in its strategic agenda (Corley and Gioia, 2004; Dutton and Penner, 1993; Gioia and Thomas, 1996). 
Organizational identity beliefs have been suggested to refer to different identity elements (Corley et al., 2006; Clark et al., 2010; Gioia et al., 2013), some of which are deemed more substantive and relatively permanent, such as an organization's philosophy and purpose for instance, whereas other elements might be deemed more transitional, such as an organization's strategic priorities as well as its daily operational practices (Gustafson and Reger, 1995). Following Reger et al. (1994; see also Margolis and Hansen, 2002; Whetten and Godfrey, 1998), we suggest organizational identity beliefs as broadly being concerned with an organization's philosophy and purpose ("who are we?"), an organization's strategic priorities (“what do we focus on?"), and an organization's daily practices ("how do we do it?").

As shown above, organizational identity beliefs are "likely to influence any attempt at transformative strategic change" (Nag et al., 2007: 824). We consider it crucial to understand in more detail how these beliefs actually shape the judgment of strategic actors regarding strategic options in strategic agenda setting.

\section{Strategic taboos in strategic agenda setting}

In order to conceptualize strategic options that are deemed out-of-bounds or off-limits due to their perceived inconsistency with the collective organizational identity beliefs, we suggest the concept of "strategic taboo" to be developed in more detail below.

Most broadly and as a socio-cultural concept, a taboo refers to a disqualified, prohibited course of action that violates normative conventions - typical examples include incest or patricide (Marshall, 2010; Webster, 1942). Being rooted in the Tongan word tapu or the Fijian word tabu meaning "under restriction," "sacred," or "prohibited," taboos combine a sense of both the forbidden and the sacred (Steiner, 1956). Taboos are concerned with issues that are not to be done, said, thought of, or felt, but that are doable, effable, feelable, and thinkable (Steiner, 1956; Webster, 1942; Zuesse, 1974). Accordingly, a taboo is a "strong social prohibition relating to any area of human activity that is sacred and even forbidden based on moral judgment or norms" (Steiner, 1956: 29). Taboos tend to be taken-for-granted in that they represent axioms that are not necessarily explicitly prohibited, but take effect as internalized rules for supposedly "normal, civilized" behavior with their assumptions and preconditions remaining inviolable (Marshall, 2010; Webster, 1942). To the extent that certain disqualified actions violate normative conventions, challenge deeply held emotional viewpoints, or cross a line into the region of the "unspeakable" or "unthinkable," they are considered as taboo (Schoemaker and Tetlock, 2012; Tetlock, 2003). As this consideration would suggest, a taboo can operate at the behavioral level in terms of prohibited action ("you ought not to do this"); at the communicative level in terms of discussing prohibited ideas and concepts ("you ought not to talk about this") as well as at the cognitive level ("you ought not to even think this") (Schoemaker and Tetlock, 2012). For our investigation, we will focus on the communicative level in terms of the discursive exploration of an intended course of action. Moreover, a taboo is reified in social norms, and its violation is judged by the respective social context.

In an organizational context, taboos constitute the unwritten norms or restraints on unacceptable, illegitimate tasks and actions that are violations of the organization's order (Argyris, 1980; Martin, 1990). They embody the shared, unquestioned, and taken-for-granted norms and "sacrosanct" values of an organization "that restrict what is considered appropriate thought, discussion, and action" (Schoemaker and Tetlock, 2012: 7). If in violation of such norms, organizational actors tend to respond by referring to a course of action as illegitimate, insulting, or absurd (Marshall, 2010). Clearly, such normative frames of reference vary between organizations; nevertheless, they are effective in influencing organizational decisions and actions more generally and strategic agenda setting by strategic actors more particularly. Hence, we define a strategic taboo as a 
disqualified strategic option deemed inconsistent with the collective organizational identity beliefs of strategic actors. A strategic taboo marks an organizational "no-go area" in that a strategic option-despite and prior to its thorough assessment—is being ignored, neglected, or deselected from the initial pool of options. If a strategic option is deemed as touching upon "sacrosanct" organizational norms and values, organizational actors are expected to defend these values at any cost (Schoemaker and Tetlock, 2012; Tetlock, 2003). In this regard, strategic taboos are both the manifestations and consequences of judgments influenced by organizational identity beliefs of strategic actors. Furthermore, we suggest that strategic taboos tend to influence the initial pool of strategic options and, consequently, risk leading to a foreshortened strategic agenda.

As we discussed above, the field would benefit from a more detailed understanding of how organizational identity beliefs influence judgments of strategic actors in strategic agenda setting. The concept of strategic taboo allows us to formulate our research question more precisely and to investigate "How do strategic actors confront strategic taboos in the process of strategic agenda setting?"

\section{Method}

\section{Choice of method and empirical setting}

Given the underexplored nature of our research focus, we opted for a revelatory inductive case study (Ketokivi and Mantere, 2010; Stake, 2005). A revelatory case study discusses a phenomenon previously inaccessible to scholarship (Yin, 2009) and enables the elaboration of theory from rich qualitative data (Patton, 2002). An ideal case setting would be an organization currently in the midst of strategic agenda setting, in which norms, values, and beliefs are salient and at stake, allowing us to track this setting of an agenda over a period of time. The strategic agenda setting process in the LCG between 2006 and 2010 is a suitable empirical setting due to its highly valueexpressive character aimed at providing spiritual guidance for its members (Golden-Biddle and Rao, 1997; Jeavons, 1992). As mission-driven organizations are founded on strong and codified normative frames of reference (McDonald, 2007; Minkoff and Powell, 2006), they are likely to be prone to strategic taboos. Specifically, any strategic option suggested in agenda setting considered in violation with the Lutheran ethos can be perceived as a strategic taboo. As per our research question, our study tracked in detail how strategic actors confronted strategic taboos in agenda setting.

\section{The case: strategic agenda setting at LCG (2006-2010)}

Overall, the LCG represents around one third of the German population (25.1 million members) with 630,000 salaried employees and more than 1 million volunteers. LCG is federation of 22 local churches, each having full formal, organizational, and theological autonomy. It is constituted in a synodal governance structure including the synod as the central legislative body, the LCG Council, and the church conference formed of representatives of the governing boards of all local churches.

In 2006, the head of LCG Council published a "strategy white paper" entitled "Church of freedom-Perspectives for the Lutheran church in the 21 st century." In this strategy white paper, a total of 12 strategic options were suggested with the explicit intention to increase the quality of core services, to implement different types of congregations within the church, as well as to create central opportunities for churchly encounters. These suggested strategic options included items such as training and educating staff, strengthening the roles and responsibilities of volunteers, centralizing administrative power at the level of the local priest, defining and specifying leadership roles and responsibilities of individual priests as well as reducing the total number of local churches. 
When the strategy white paper and its 12 strategic options were presented to a wider internal audience, the items "centralizing administrative power at the level of the local priest" and "defining and specifying leadership roles and responsibilities of individual priests" were initially deemed as being at odds with the Lutheran ethos and some of its foundational doctrines. Together, these two options were intended to define and specify the role of the local priests as managers in that the priests "need a specific competency for leadership and communicating tasks. The priests and the other employees in leadership positions will take on a central role in creating the paths into the future" (LCG Strategy White Paper, p. 13). Consequently, establishing corresponding leadership structures were suggested as

bringing a clear assignment of leadership responsibility in the church, being open for modern, quicker decision making processes, a clearer distinction between the management and theological leadership, in order to benefit and make better use of the elements of a modern leadership culture. (LCG Strategy White Paper, p. 14)

In their initial assessment, most internal actors, commentators, and readers deemed both strategic options as being in conflict or even in contradiction with two main theological doctrines of the LCG. First, the doctrine of universal priesthood (or "priesthood of all believers") posits that the Lutheran church has been founded and based on equality of its members. Every member of the church - whether ordained or not - is considered to be an integral and constitutive element of the church with the right of leadership being anchored in the congregation (Slok, 2009). Adjacent to this first doctrine, the second doctrine of holding no ruling power over others suggests that the church should not assign or exert itself dedicated decision rights over its members. Hence, both of these Lutheran doctrines suggest no personal superiority; instead, every individual is viewed as being responsible for his or her own spirituality and of equal status in the eyes of God (Miller, 2002; Slok, 2009). In concert then, these two doctrines embody what we refer to in the argument as the "Lutheran ethos" or LCG's organizational identity beliefs that historically have guided the church's organizational structure and processes.

With regard to the proposed issues of centralizing administrative power and enhancing the leadership role of the priests, one external journalist commented as follows: “... these claims are close to taboo breaking. Whoever realizes the contradictions that collide together in these issues quickly recognizes the explosive aspects lying behind these claims" and "it is about a topic, that is and has always been a taboo topic in German Protestantism, namely, the topic of "legitimate authority"' (external press article). Addressing the priest's authority and leadership role was seen as contradicting the theological-doctrinal tradition that the congregation is the final seat of authority since the right of leading the church is being anchored in the Lutheran membership.

As the authors of the strategy white paper anticipated that their suggested strategic options would be assessed for compatibility with the Lutheran ethos, they invited comments and feedback on the strategy white paper from all parts of the church. This participatory strategy process was intended to stimulate exchange, negotiation, and critical reflection on the proposed strategic options between administrative, theological, as well as lay members from inside and outside the church. In a way, the strategy process itself embodied the Lutheran ethos of equality and participation.

In 2010 - and after a thorough and controversial (mainly written) debate - the two initially disqualified strategic options were included on LCG's strategic agenda in that they appeared in protocols, speeches, and minutes, and in that decisions were made upon these issues. Thus, the focus of our empirical inquiry is on the process through which the strategic actors evaluated these two strategic taboos to finally integrate these issues onto LCG's strategic agenda. 


\section{Data sources}

Our case data base comprises written documents of various genres (e.g. strategy papers, external press articles, proposals, internal documents), 19 interviews, and field observations of meetings and workshops covering a total of 4 years (2006 retrospective; 2007-2010 in real-time). The first author collected data over 20 months during the formulation of the strategy. The selection of the data sources was informed by our focus of inquiry, namely, to capture relevant and indicative data that allow us to explore how the actors confronted strategic taboos. In this respect, we followed Glaser and Strauss' (1967) suggestion to triangulate from diverse sources of data to obtain multiple vantage points into the phenomenon of inquiry.

Documents. As the strategy process took mainly a written form, documents form the primary data source in our case and provide a running history of how our two objects of inquiry developed across periods. Interviews served as a secondary source to contextualize and sharpen our hermeneutic apparatus and provided an important supplementary triangulation source for understanding events from various perspectives (Strauss and Corbin, 1990). In particular, we collected 1366 pages of documents with comments, viewpoints, or arguments on a specific strategic option laid out in the strategy white paper or the overall strategic change process itself.

Overall, the documents comprised of five forms: (1) strategy papers, which included papers and electronic statements about the new strategic direction; (2) documentation books, entailing statements and comments on the strategy debate that were summed up and published by the church office members; (3) press articles; (4) internal documents and reports from the Synod; and (5) contextual material, including papers being published by the members of the church organizations or the local churches.

Interviews and field observations. The first author conducted two expert interviews as well as three group interviews with the members of the reform project office (32 pages; 50-60 minutes on average; transcribed verbatim). Furthermore, 14 semi-structured interviews were conducted from February 2007 to July 2009 (161 pages; 40-50 minutes on average; transcribed verbatim). In order to identify relevant informants with insight into the organizations' structure, strategies, and actions (Kumar et al., 1993), we generated a list of members who (1) were actively managing the strategic change process (e.g. head of the Council, heads of local churches), or (2) were actively involved in the process (e.g. members of the strategy task force or the steering group), and (3) were in a position to recommend additional informants at all levels within the organization (e.g. members of the Synod). A careful reading of the documents allowed us to identify additional members who were particularly engaged in the current debate by frequently and critically commenting on developments. In addition to the interviews, the first author attended three workshops, observed seven reform project meetings from 2007 to 2010, and captured these observations in field notes ( 56 hours of observations; 34 pages). Table 1 provides an overview of the case history and exemplifies the underlying data sources along with their uses in analysis.

\section{Analytical strategy}

Data analysis drew upon established approaches for qualitative studies (Miles and Huberman, 1994; Patton, 2002; Strauss and Corbin, 1990). In following an inductive approach to theory elaboration (Stake, 2005), we moved back and forth between the data and an emerging theoretical understanding of strategic taboos in the case setting. We focused on how church members responded to what they perceived as strategic taboos, and how they confronted the issues they saw as conflicting 


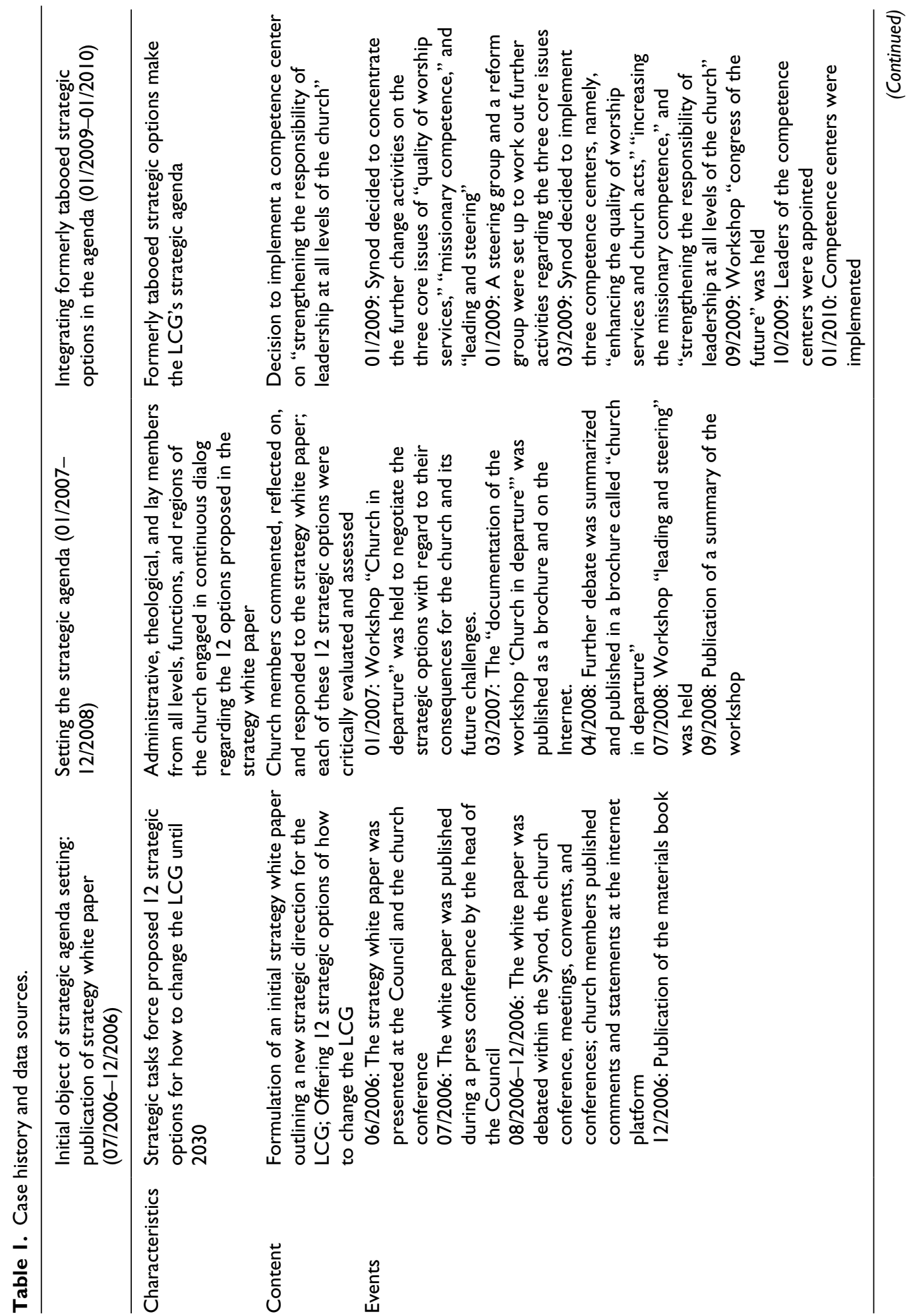




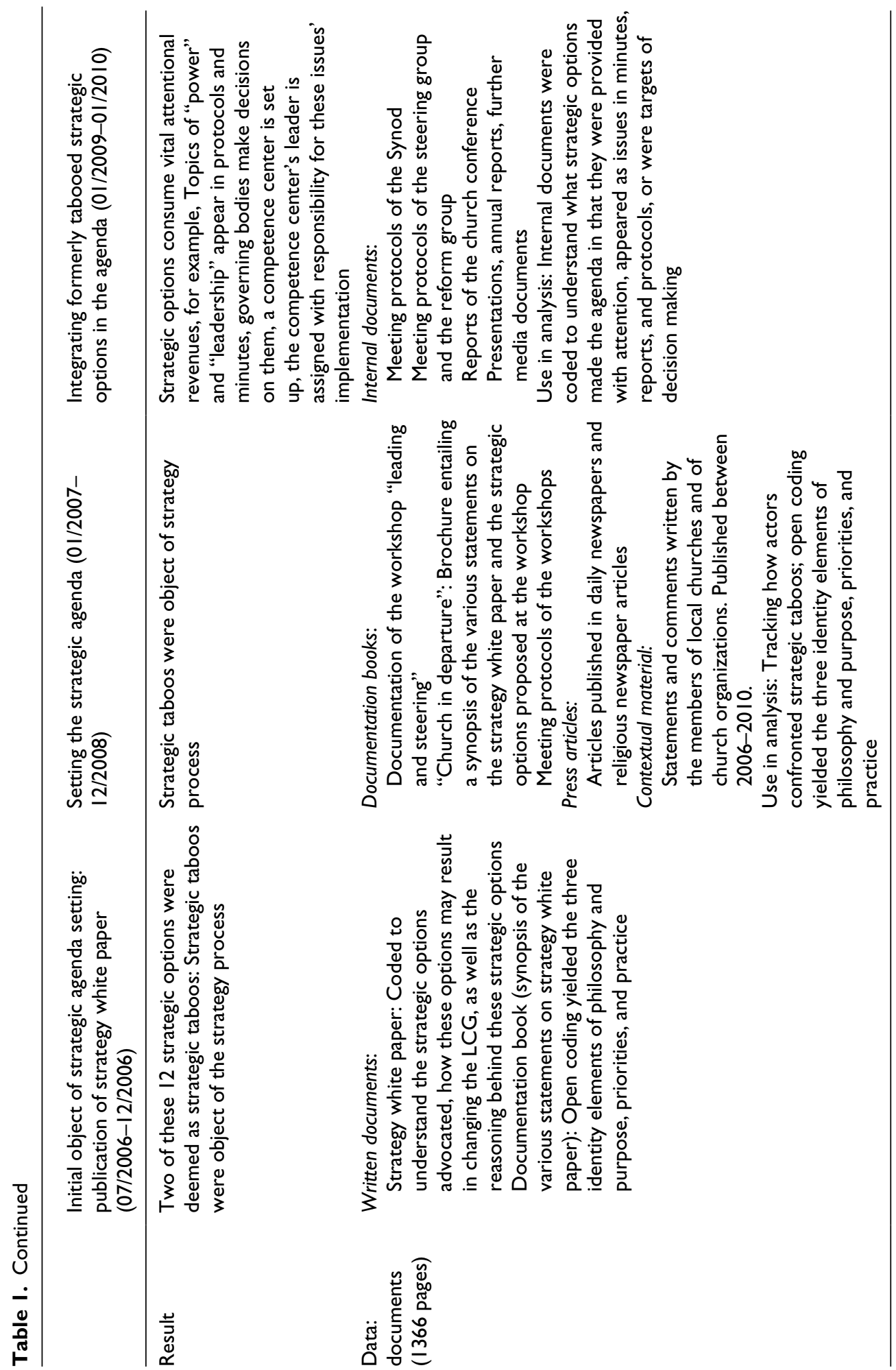




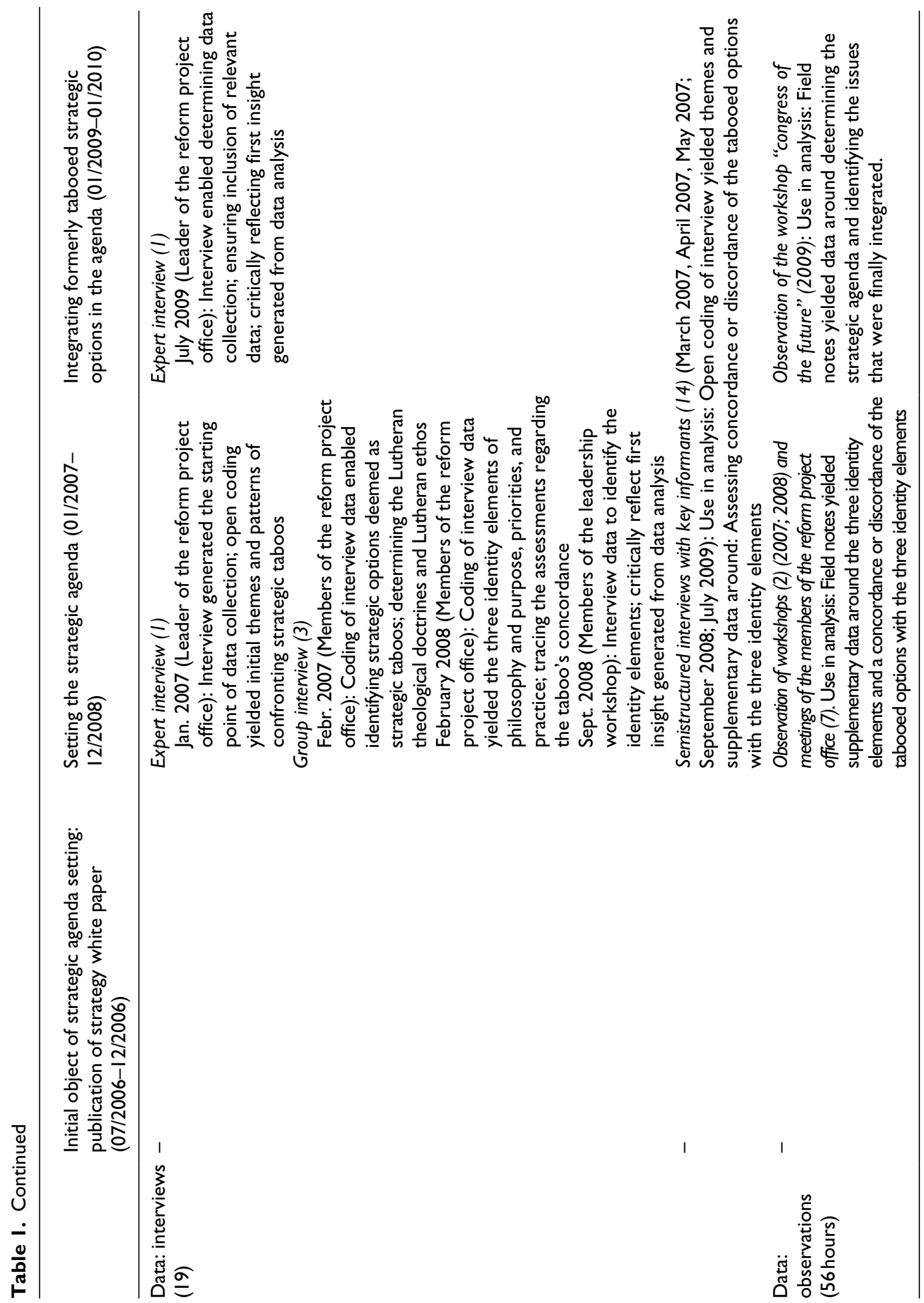


with established norms and values of the organization. Our analysis progressed in four steps as we developed and refined our findings toward a typology of practices of reinterpretation employed by organizational actors when confronting strategic taboo.

Creating a chronology of the case. Using QDA Miner, we created an event history of the case that provided a chronology of the strategic change process (Langley, 1999; see Table 1). We coded what our informants deemed as critical events in the strategy process and matched corresponding data to each event. We then checked for comprehensiveness in our data set.

Identifying the unit of analysis. In order to understand how strategic actors confronted strategic taboos, the second stage aimed at identifying and validating what our informants deemed to be strategic taboos. Based on field observation, critical reading of the ongoing debate, and dedicated group interview, the first author solicited key informants' view on which of the initial 12 strategic options they saw causing the most discomfort in the LCG's strategy process. Two of the 12 options, namely, "centralizing administrative power at the level of the local priest" and "defining and specifying leadership roles and responsibilities of individual priests," stood out as being disqualified due to their lack of fit with the Lutheran ethos - these are the issues that we labeled "strategic taboos" in this context.

Tracking the unit of analysis in our data set. Subsequently, the first author tracked these two strategic taboos in the case event history and analyzed how each was voiced, paraphrased, and judged. We began to identify all statements on the two strategic taboos via open coding - a procedure that breaks data down into instances for comparison and reassembles the data in new ways (Strauss and Corbin, 1990). Afterward, we drew on common statements to form initial categories defined as situationally specific factors directly connected to the actors assessing the strategic taboos. To enhance the validity of the emerging codes (Miles and Huberman, 1994), after the codes were labeled and categories were constructed, we reviewed the data again to see which, if any, fit each category.

Development of the typology. The main challenges in inductively moving from particular observed events to abstract concepts lie in building transparency and consistency in theoretical explanations (Ketokivi and Mantere, 2010). To draw theoretical conclusions from our data, we started by identifying conceptual categories and relationships emerging from the coding and analysis of our findings. To arrive at the best explanation for our data, we linked back to prior literatures on strategic agenda setting, organizational identity, and taboos, and then returned to the data to perform further rounds of coding and comparisons. By iterating between theory and data, we further clarified and focused our findings and theoretical arguments. Together, these activities helped us to develop a typology of reinterpretation practices that strategic actors employ when confronting strategic taboos.

\section{Field analysis: confronting strategic taboos in agenda setting at LCG}

Based upon our field analysis, we now present our findings of how strategic actors in the LCG's strategy process confronted the tabooed strategic options of "centralizing administrative power at the level of the local priest" and "defining leadership roles and responsibilities for priests" by way of assessing concordance of the taboo with organizational identity elements. Each of these assessments is concerned with a specific element of the actors' organizational identity beliefs that we derived from our field analysis and that are grounded in first-order themes and second-order concepts. In a first step, we show how we derived our aggregate dimensions, namely, the concordance assessments regarding key identity elements, from our 
- "Power and leadership links back to our most fundamental Lutheran principle"

- "The Lutheran doctrines and principles constitute the goals that we hold as legitimate objectives and that separate us as a church from others, even from the Catholic Church" (internal document).

\section{NORMATIVE AUTHORITIES}

- "These (organizational) structures are rooted in the congregations, with the consciously made decision beneath the cross; we give order to the church so that the normative elements, which do support us, are made manifest" (external newspaper article).

- "We are a church founded on the faith of God" (interview).

\section{SURVIVAL}

- "The will of the Lutheran church is to bring to light the vitality and beauty of the Evangelism. People should experience, even in the $21^{\text {st }}$ century, what it means to live off the freedom of faith" (interview).

- "Keeping alive what Martin Luther founded 500 years ago" (internal document).

\section{CARRYING THE FAITH TO THE PEOPLE}

- "Our Church is founded on carrying the faith to the people and that's been the fundamental goal all the way through from the beginning and still is" (internal document).

\section{PRIESTLY WORK}

- "We have to deliver a special service in our congregations and the priest do have their specific routines in carrying it out" (interview).

- "When we speak about leadership we speak about how priest (...) organize their congregational life" (internal document).

\section{ACTUAL LEADERSHIP}

- "Our type of organization reminds us that our congregational life and the interactions between the members of the clergy, of the congregation, and of the local churches are founded on consensus and equality" (internal document).

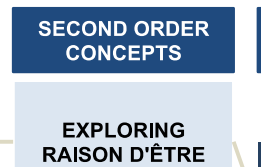

\section{AGGREGATE}

DIMENSIONS

RAISON D'ÊTRE

ENROLLING

NORMATIVE

AUTHORITIES

ACKNOWLEDGING

SURVIVAL

PROBLEMATIZING

GOALS

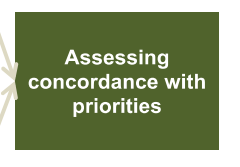

Assessing

concordance with
philosophy and purpose

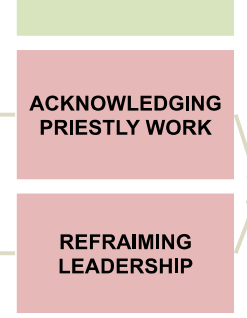

Assessing

concordance with practices

Figure I. Data structure.

field analysis (Figure 1). We structure our findings along from more relatively permanent and substantive identity elements to more transitional ones, namely, philosophy and purpose, priorities, and practices - a distinction we introduced earlier in the positioning section (Clark et al., 2010; Corley et al., 2006).

LCG's philosophy and purpose is grounded and reflected in the Lutheran ethos and its corresponding doctrines in terms of the church's distinctive attributes that transcend any particular service, time, or environment. LCG's priorities constitute a further element of organizational identity beliefs that entails the goals and directions LCG focuses on. Finally, LCG's practices pertain to actual leadership behavior, services, and daily activities. This identity element constitutes what the organizational members see as an important, but less central part of their organization. We now present each concordance assessment in turn.

\section{Assessing concordance of strategic taboos with LCG's philosophy and purpose}

At LCG, the strategic options suggested by the strategy white paper were for the most part deemed consistent with its identity beliefs - while two of these options were considered to be off-limits nevertheless. When these tabooed options came under critical scrutiny, the members explored these options in terms of their concordance with the church's foundational philosophy and purpose. Empirically, the members assessed the tabooed options in terms of two aspects of LCG's philosophy and purpose, namely, its raison d'être as well as its normative authorities. We present these aspects in turn (Figure 2). 


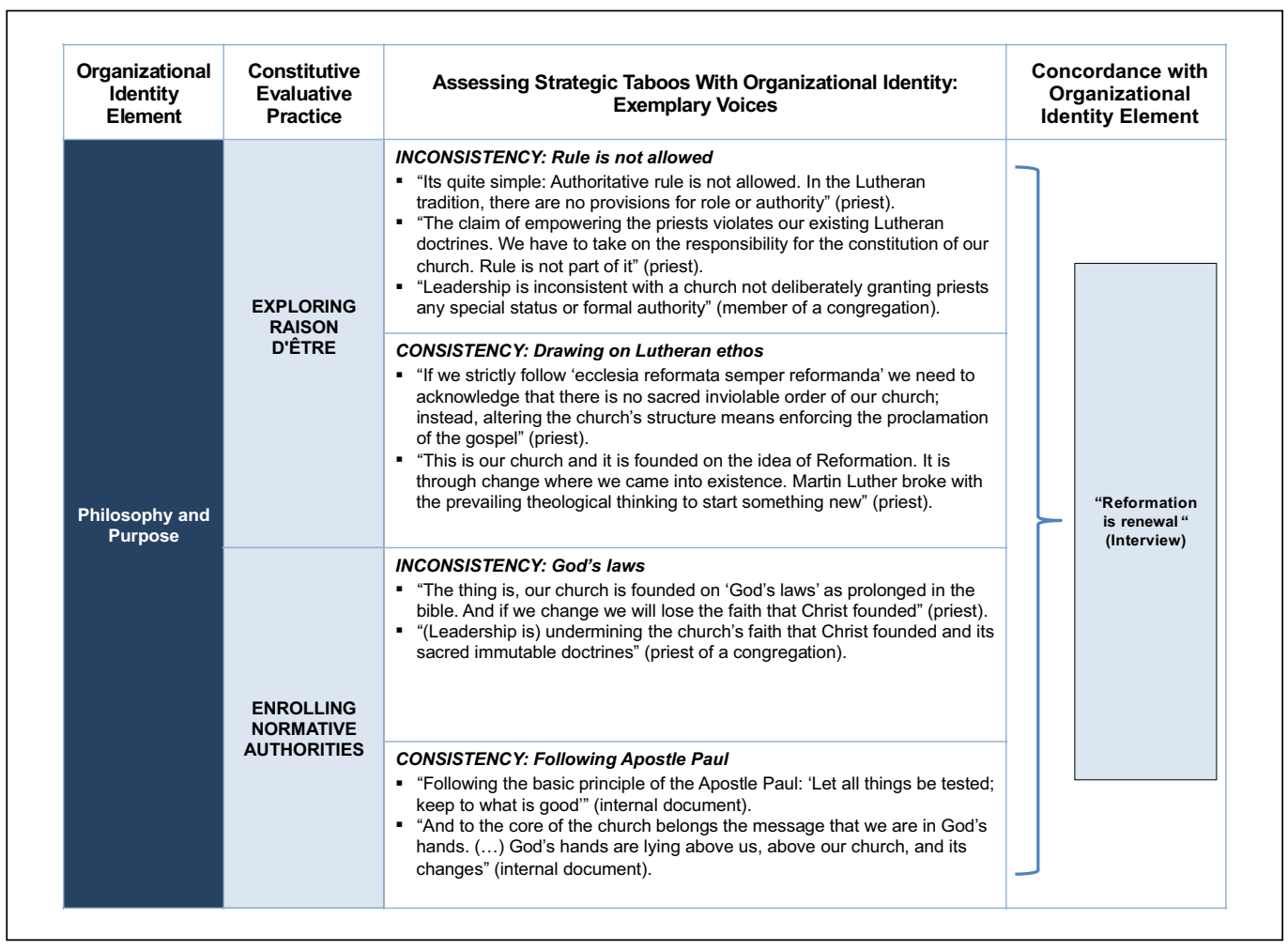

Figure 2. Data display: assessing concordance with LCG's philosophy and purpose.

For instance, when assessing the taboos in terms of their concordance with LCG's raison d'être, one member of the church deemed a more directive leadership role of priests as violating LCG's foundational Lutheran doctrines: "It's quite simple: Authoritative rule is not allowed. In the Lutheran tradition, there are no provisions for rule or authority." Furthermore, the members also drew upon LCG's doctrines to argue that both strategic options are in conflict or even in contradiction with these theological foundations. For example, a congregational member referred to the doctrine of universal priesthood (or "priesthood of all believers") and posited that "the Lutheran church has been based on equality of its members." He assessed a more directive leadership role as inconsistent with a church not deliberately granting priests any special status or formal authority. The "church's sacred immutable doctrines" was also mobilized by a priest stating that "the doctrine of holding no ruling power over others suggests that the church should not exert decision making power on its members." Given that this Lutheran doctrine suggests no personal superiority, she deemed a directive leadership role as inconsistent with a church in which every individual is viewed as being responsible for his or her own spirituality. Furthermore, advocates of an inconsistency between the taboo and LCG's raison d'être aimed at substantiating the argument by stressing that "the Lutheran tradition and more precisely the presbyterian-synodal order is not an organizational option that is changeable" (member of a congregation).

When assessing concordance of the taboos in terms of LCG's philosophy and purpose, members explored and discussed the taboo's concordance also with respect to normative authorities - such as God, Jesus Christ, or the apostles. For instance, a newspaper article by a priest suggested power 
and leadership roles for priests as being "off-limits" since these aspects were likely "to undermine the faith that Christ founded" (priest of a congregation). By mobilizing LCG's normative authorities, various members advocated these issues' discordance with the rules that God gave. A priest, for example, advocated the taboo's discordance by stating "our church is founded on 'Gods laws' as prolonged in the bible."

On the other hand, proponents of a concordance of the taboos with LCG's raison d'etre challenged this premise of a sacred, inviolable order by mobilizing the principle "ecclesia reformata semper reformanda." This adjacent Lutheran principle suggests continuous renewal as a central part of their Lutheran tradition. As one member stated, "Reformation is a remembrance and an encouragement: A remembrance of the impulse and of the origin from which the church comes to life - and an encouragement to constantly reflect on itself, to constantly reform itself, wherever deemed necessary." Another members' comment reflects the entanglement with this Lutheran principle by describing as follows:

It is through change that we came into existence. Martin Luther broke with prevailing theological thinking to start something new. For sure, our Lutheran ethos is what we believe in; however, the idea of Reformation still is and should become our most important resource to draw upon.

The member further stated that enhancing the leadership roles of the priests is to be understood as consistent with a church engaging into its constant renewal. As a consequence, changing the priest's roles toward more centralized leadership structures was deemed consistent with LCG's raison d'être.

Equally here, normative authorities were mobilized to advocate a stronger leadership role for the priests as a strategic option in accordance with LCG's philosophy and purpose. Several church members enrolled an apostolic principle attributed to Paul, namely, "Following the basic principle of the Apostle Paul: "Let all things be tested; keep to what is good"' (LCG Internal document, p. 13). Proponents of concordance mobilized this quote as to substantiate their claim for a spiritual justification of the continuous renewal of LCG. By mobilizing Apostle Paul's principle, these church members stated an enhanced leadership role of the priests as consistent with this principle's plead for testing all things. In particular, one congregational member commented, "Granted, if we enhance the leadership role of our priests, our congregational life will change." She further proposed that this new leadership role is consistent with what Apostle Paul spiritually claimed and concluded with questioning "why shouldn`t we just try things out?" (LCG Internal document, p. 31). Furthermore, members advocating the taboo's consistency drew upon normative authorities in terms of God's hands and stated, "To the core of the church belongs the message that we are in God's hands. This is the anchor, giving us security - making us free. God's hands are lying above us, above our church, and its changes." Finally, the taboo's consistency was advocated by claiming, "No halt exists under the sun of God. Changed leadership structures in our congregations and in our church keeps us going, every one for himself, we together as a congregation and a church" (LCG Internal document, p. 132).

\section{Assessing concordance of strategic taboos with LCG's priorities}

Furthermore, the members explored the issues of power and centralizing leadership structures in terms of their concordance with the church's priorities. They engaged in the practice of exploring the concordance of the tabooed options with what they believe LCG has to focus on and to give special attention to. Empirically, they assessed the two options in terms of two aspects of LCG's priorities, namely, its survival as well as its foundational goals (Figure 3). 


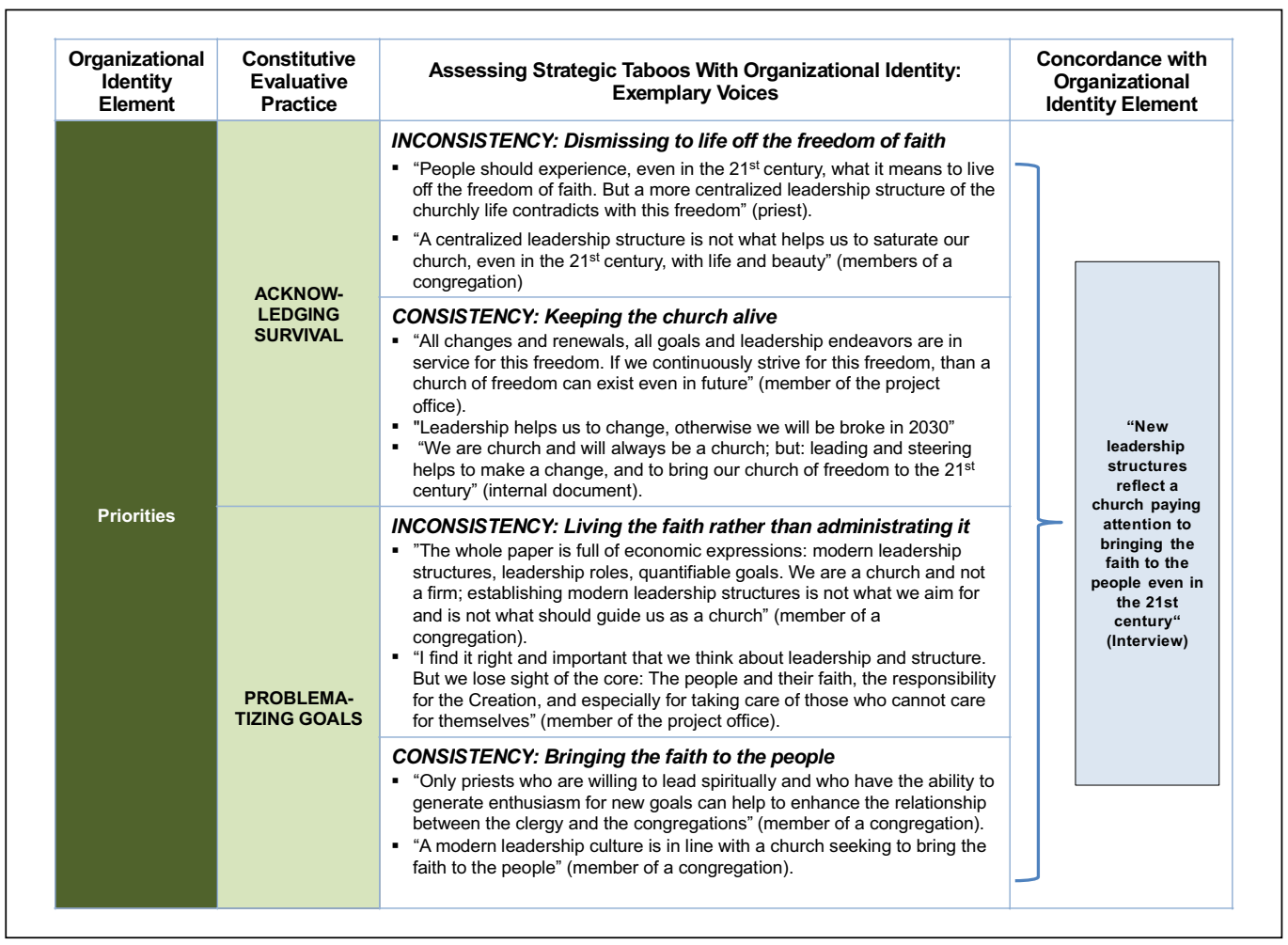

Figure 3. Data display: assessing concordance with LCG's priorities.

When assessing the taboos in terms of LCG's priorities, the members explored and discussed the taboo's concordance with respect to LCG's survival. The church members drew upon LCG's priorities regarding substantiating what Martin Luther founded 500 years ago. In various statements, they deemed a more directive leadership role of the priests as inconsistent with securing LCG's future until the 21st century. For instance, one member stated,

The will of the Lutheran church is to bring to light the vitality and beauty of the Evangelism. People should experience, even in the $21^{\text {st }}$ century, what it means to live off the freedom of faith. But a more centralized leadership structure of the churchly life contradicts with this freedom.

Furthermore, advocates of an inconsistency between the tabooed options and LCG's priorities aimed at substantiating the argument by stressing that "a centralized leadership structure is not what helps us to saturate our church, even in the 21 st century, with life and beauty" (member of a congregation).

Equally here, LCG's goals of bringing the faith to the people were mobilized to advocate a stronger leadership role for priests as a strategic option in discordance with LCG's priorities. Within this view, one member claimed that "the church as a fellowship of believers has to give honor to God only. The church has to take care that it provides the people with faith through its message and its order" (LCG Internal document, p. 154). Accordingly, the proponents advocated that power and centralized leadership structures contradict with what LCG pays special attention to. Several other members highlighted this inconsistency with one congregational member 
concluding, "We have to live the faith, rather than administrating it." Discordance between the taboo and LCG's goals is also evident in the following comment:

The whole paper is full of economic expressions: modern leadership structures, leadership roles, quantifiable goals. We are a church and not a firm; establishing a modern leadership is not what we aim for and it is not what should guide us as a church (member of a congregation).

Accordingly, the issues of power and leadership were evaluated as inconsistent with a church longing for providing the people with faith. A member stated,

I find it right and important that we think about leadership and structure. But we lose sight of the core: The people and their faith, the responsibility for the Creation, and especially for taking care of those who cannot care for themselves.

On the other hand, proponents of a concordance of the taboos with LCG's priorities challenged the survival of their church and justified the tabooed issues as in line with "bringing our church of freedom to the 21 st century." One of these proponents wrote, "Naturally, the conditions of freedom have change so dramatically that today we have to tell about the freedom in a new way and differently from what Martin Luther told in Wittenberg 500 years ago" (LCG Internal document, p. 150). "As a consequence," the church member further claimed, "all changes and renewals, all goals and leadership endeavors are in service for this freedom. If we continuously strive for this freedom, than a church of freedom can exist even in the future." LCG's priority of bringing the church of freedom to the 21 st century was also mobilized by a congregational member who explored the issues of power and leadership regarding the economic future of the church. He stated, "Leadership helps us to survive, otherwise we will be broke in 2030" and evaluated the issues of administrative power and leadership roles as consistent with LCG's priorities to "maintain and renew our church even until 2030." In this view, the issues of power and centralized leadership structures were deemed as consistent with endorsing the future of the church, thereby allowing the church to "give itself a wider space of possible directions on how to survive." By mobilizing LCG's survival, one member argued, "Authority and leadership are at odds with usbut we all want our church to survive, even after 2030, and to maintain the gospel values of justice, mercy, and participation [...]."

Equally here, LCG's goals were mobilized to advocate a stronger leadership role for the priests as a strategic option in concordance with LCG's priorities. For justifying consistency of the tabooed options, in an interview, one priest claimed LCG's goal as providing the Lutheran people with faith and emphasized that a new leadership role of the priests is in line with these provisions. The members collectively advocated consistency of a modern leadership culture with LCG's goal of bringing faith to the people because "only priests who are willing to lead spiritually and who have the ability to generate enthusiasm for new goals can help to enhance the relationship between the clergy and the congregations" (LCG Internal document, p. 42).

\section{Assessing concordance of strategic taboos with LCG's practices}

Furthermore, the issues of power and centralizing leadership structures were evaluated in terms of their concordance with LCG's practices. Here, the church members engaged in assessing the consistency of the tabooed options in terms of how they believe LCG is distinctively carrying out its procedures, services, and day-to-day activities. Empirically, the members assessed the two options in terms of two aspects of LCG's practices, namely, priestly work and actual leadership (Figure 4). 


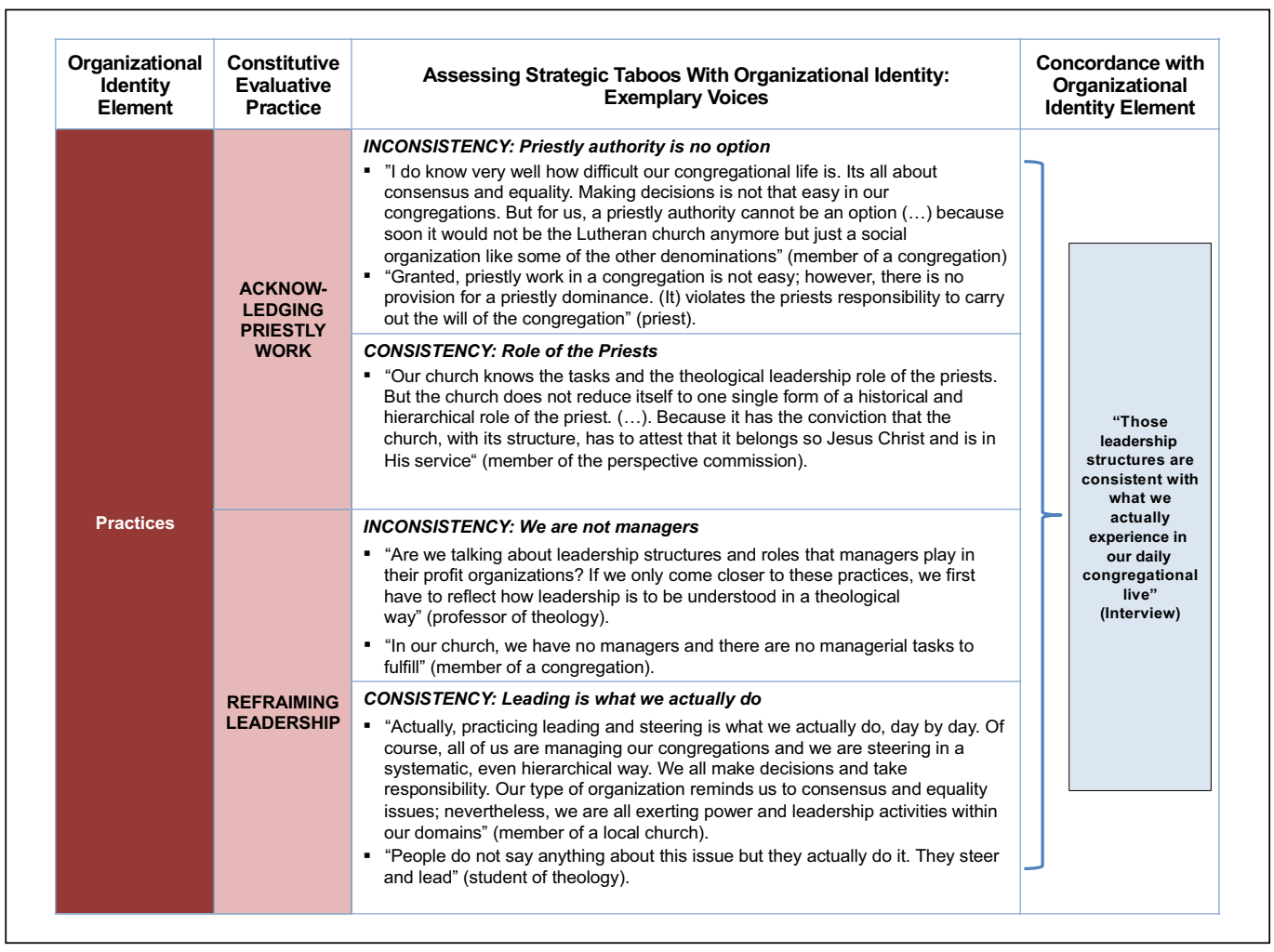

Figure 4. Data display: assessing concordance with LCG's practices.

Various members deemed a more directive leadership structure as inconsistent with how they understood LCG's practices regarding the priestly work, and the activities and practices that the priests use. For example, in workshops and symposia, church members engaged in speeches and in round table discussions on the roles and tasks of priests as well as the theological facets of the priestly work. The attendees of the workshops emphasized the relationship between the priests and the congregation as being characterized by participation, consensus, and equality. From this perspective, enhancing the leadership role of the priest was deemed as inconsistent with a church being obliged to open participation. For example, a lay member stated,

I do know very well how difficult our congregational life is. But for us, a priestly authority cannot be an option $[\ldots]$ because soon it would not be the Lutheran church anymore but just a social organization like some of the other denominations.

Other proponents also highlighted the tabooed issues' inconsistency with LCG's practices by claiming that Lutheran priests are being assigned with the primary responsibility to carry out the will of the congregation. Consequently, the priests have no formal authority to induce conformity to their directives apart from what had been granted from the congregation. In these statements it is argued, "For sure, a priests' position in his congregation is not easy-however, there is no provision for establishing priestly dominance" (LCG Internal document, p. 154). 
Equally, the tabooed options were evaluated against what the church members understood to be the actual need for leadership in the church. Attendees of the workshop critically stated that more centralized leadership structures are inconsistent with LCG's current practices. For instance, one of the attendees highlighted, "In our church, we have no managers and there are no managerial tasks to fulfill in our congregational life. Instead of centralized decision making structures and top-down directives, our congregations are saturated with the spirit of consensus and equality."

While some members strictly adhered to the tabooed option's inconsistency with LCG's practices, the priestly work was also mobilized by those members who claimed the issues of enhancing power and leadership as consistent with LCG's day-to-day activities. Those members claimed that LCG is not strictly adhering to a certain form of how priests have to fulfill their theological functions and tasks because

our church knows the tasks and the theological leadership role of the priests. But the church does not reduce itself to one single form of a historical and hierarchical role of the priest. The church is not at all indifferent regarding the questions of the visible structure of the church. Because it has the conviction that the church, with its structure, has to attest that it belongs to Jesus Christ and is in his service.

Consequently, those members advocated that an enhanced leadership role of the priests is concordant with a church not being limited in its priestly work.

Other proponents of concordance emphasized that LCG's practices and how congregational work is organized are to be understood as leadership activities. For example, one member wrote, "When we speak about leadership, we speak about how priest, lay members and all the others organize their congregational life" (LCG Internal document, p. 95). With regard to how congregational life is practiced at LCG, one interviewee observed,

What we all realized was that leading and steering, this is what we actually do, day by day. Of course, all of us are managing our congregation and we are steering in a systematic, even hierarchical way. We all make decisions and take responsibility. Our type of organization reminds us about consensus and equality issues; nevertheless, we are all exerting power and leadership activities within our domains.

Hence, the members drew upon LCG's practices to justify consistency between enhancing power and leadership roles and how the congregational life is actually organized at LCG.

We now turn to a conceptual reflection of the case as to develop a typology of the practices of reinterpretation strategic actors employ when confronting strategic taboos.

\section{Confronting strategic taboos-three practices of reinterpreting organizational identity}

Based on a second-order abstraction of our analysis of how LCG strategic actors confronted the two context-specific strategic taboos in the strategy process and in aspiring to a moderate level of generalization (Payne and Williams, 2005) from our case, we offer in the following our theorizing and development of the practices of reinterpretation strategic actors employ when confronting strategic taboos.

First, we suggest that strategic actors confront strategic taboos by assessing the concordance of strategic taboos with organizational identity beliefs. Such concordance assessment involves the reinterpretation of key elements of organizational identity, namely, philosophy and purpose, priorities, and practices. This reinterpretation involves three types of practices that each are concerned with a specific organizational identity element, including contextualizing (philosophy and purpose), 


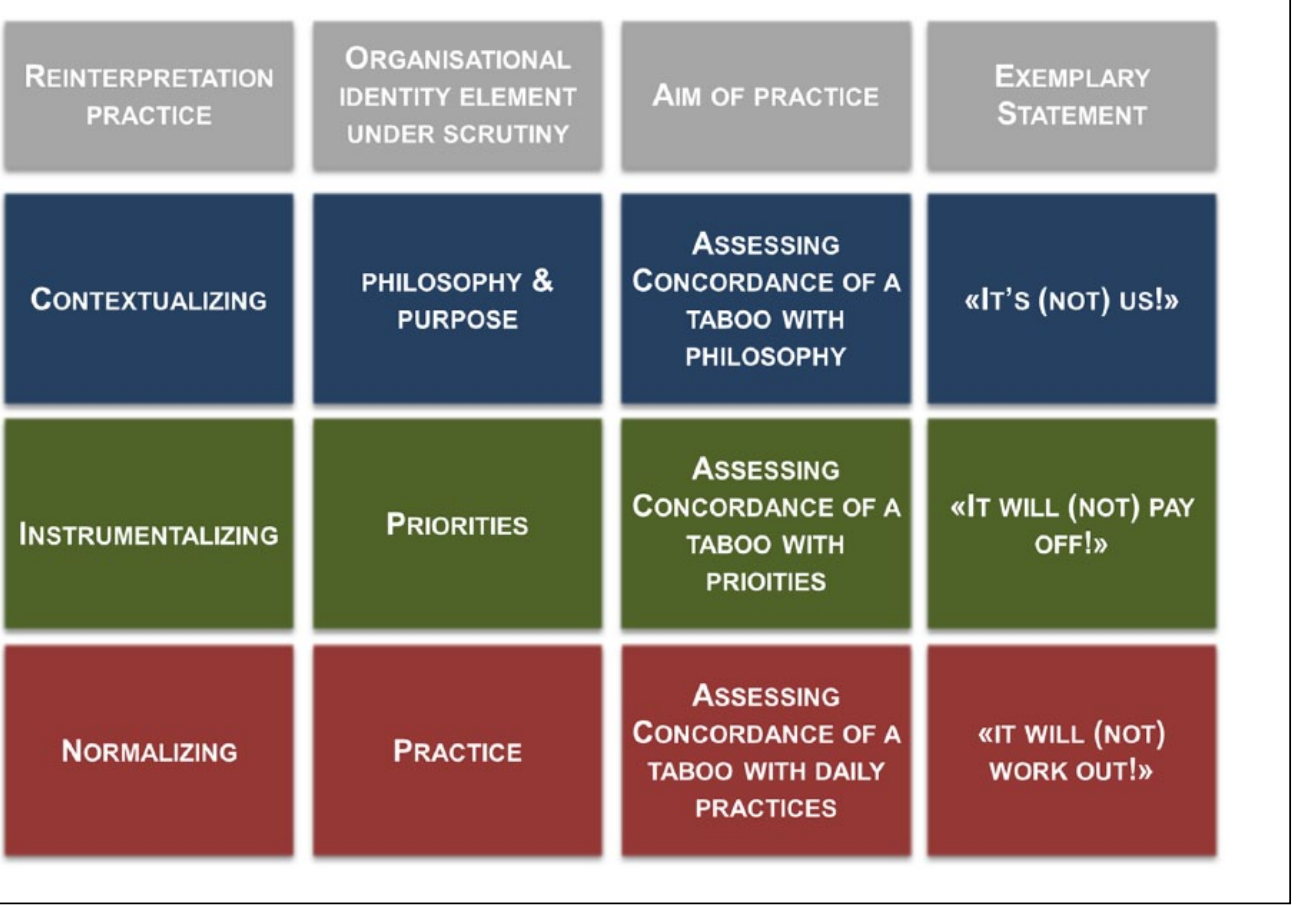

Figure 5. A typology of practices of reinterpreting organizational identity elements.

instrumentalizing (priorities), and normalizing (practices). Finally, we note that each practice not only refers to the same identity elements but moreover that these elements are mobilized by strategic actors similarly advocating concordance or discordance of a taboo with a specific identity element. Figure 5 summarizes these considerations. We discuss each of these three aspects in turn.

Even though the identification of what qualifies as a strategic taboo might be highly contextual, any strategic option initially deemed out of bounds is being assessed in light of an organization's collective identity beliefs. More specifically, this assessment refers to critically juxtaposing the strategic taboo with important aspects of organizational identity. Overall, we suggest that strategic actors confront strategic taboos by assessing the concordance of a strategic taboo with key elements of organizational identity, namely, philosophy and purpose, priorities, and practices (Clark et al., 2010; Corley et al., 2006).

Thus, confronting strategic taboos pertains to assessing concordance with any and all of these three organizational identity elements. Strategic actors evaluate the degree of potential violation of or concordance with an initially disqualified strategic option with a given set of these organizational identity elements by reinterpreting their organizational identity beliefs in light of the taboo. We suggest that this reinterpretation takes the form of three practices of reinterpretation whereby each of these is concerned with a specific key element. We present each of these in detail below.

\section{Three practices of reinterpreting organizational identity: contextualizing, instrumentalizing, and normalizing}

In our case analysis, we find that strategic actors drew on distinct practices of reinterpreting organizational identity elements in their assessment of strategic taboos. Each of these practices is 
concerned with a specific identity element, namely, contextualizing with philosophy and purpose, instrumentalizing with priorities, and normalizing with practices. We elaborate on each practice below.

Contextualizing: assessing the concordance between taboo and philosophy and purpose. In LCG, we observed how strategic actors mobilized two important elements of LCG's philosophy and purposeraison d'être as well as normative authorities - when exploring consistency of two strategic taboos. Furthermore, advocates and skeptics alike drew on these elements when reinterpreting organizational identity beliefs for their cause. We propose that this practice of reinterpreting philosophy and purpose of an organization in light of a strategic taboo can be generalized into a practice of reinterpretation we term "contextualizing." The practice of contextualizing pertains to assessing whether and how a strategic taboo is in concordance with an organization's overall philosophy and purpose - an abstract, yet fundamental identity element that establishes the context for the organization. In other words, strategic actors aim at assessing whether a strategic option "fits" within an organization's "ideological" context. We propose that the practice of contextualizing aims at specifically advocating or denying concordance of a taboo with an organization's philosophy and purpose.

Instrumentalizing: assessing the concordance between taboo and priorities. The practice of assessing concordance between taboo and organizational priorities is what we claim as "instrumentalizing." In LCG, we observed church members assessing the two strategic taboos against the church's longterm survival as well as the "eternal" goals LCG has to amend. Thus, strategic actors assessed whether the two taboos were consistent with LCG's overall organizational priorities, such as bringing the church of freedom to the 21 st century as well as the goal of carrying the gospel to people. Again, the identity element of an organization's priorities was mobilized by advocates and skeptics alike. We propose this reinterpretation of an organization's priorities in light of strategic taboos as the practice of instrumentalizing. Hence, instrumentalizing is concerned with assessing concordance between the taboo and the organization's priorities and in this with assessing the "instrumental" value of including an initially deemed off-limits option in the strategic agenda. While contextualizing explores a taboo's overall ideological fit, instrumentalizing explores a taboo's possible "pay off" for the organization.

Normalizing: assessing concordance between taboo and practices. Finally, with regard to assessing concordance between taboo and practices, LCG's actors were concerned with how the two strategic taboos resonated with actual organizational practice in the church's congregations as well as the actual management and leadership activities, respectively. Thus, strategic actors in LCG assessed concordance of the taboos with the identity element of practices. Again, we believe that this finding has broader relevance and thus suggest this practice of reinterpretation as "normalizing."

Normalizing pertains to assessing accordance between a strategic taboo and what actors deem "actual" (rather than espoused) daily practices in an organization. We propose that the practice of normalizing accounts for concordance of a strategic taboo with what an organization believes to be "doing anyway" and how foreign or normal, for that matter, the taboo might actually prove at a practical level of identity. While instrumentalizing is concerned with whether a taboo is consistent with an organization's priorities, normalizing explores whether and how a taboo might be compatible with organizational practice. Equally, advocates and skeptics drew on the same identity element when arguing their case.

Practices of reinterpreting organizational identity beliefs. Conceptually, we consider the practices of contextualizing, instrumentalizing, and normalizing as an interpretive endeavor and accomplishment. We propose that assessing concordance of a strategic taboo with identity elements consists 
in reinterpreting organizational identity beliefs in ways that make them consistent with what organizational actors deem the right course of action. When exploring concordance, organizational actors draw on their organizational identity beliefs as an interpretive repertoire as to assess the concordance of a strategic taboo. Rather than substantively challenging, amending, or even changing the identity beliefs, the latter are mobilized as an interpretive device to make sense of the taboo. By contextualizing, instrumentalizing, and normalizing, organizational actors not only use the identity element to assess an issue's consistency, but they also reinterpret each of these elements. Instead of fundamentally questioning the identity beliefs, strategic actors draw on those beliefs, thereby making them broad enough to account for consistency.

\section{Discussion}

As a broad and comprehensive strategic agenda has been suggested as vital for fundamental strategic change (e.g. Greenwood and Hinings, 1996; Tushman and Romanelli, 1985), we set out to explore how the judgment of strategic actors, when selecting strategic options for a strategic agenda, might be influenced by their organizational identity beliefs. We defined strategic taboos as those strategic options initially disqualified and deemed inconsistent with the organizational identity beliefs of strategic actors. We investigate how strategic actors confront strategic taboos in the process of setting an organization's strategic agenda. Based on our empirical analysis, we find that strategic actors engage in assessing the concordance of the strategic taboos with organizational identity beliefs and, more specifically, that they focus on key identity elements (philosophy, priorities, practices) when doing so. We develop a typology of three practices of reinterpretation that each is concerned with the aforementioned key identity elements. While contextualizing assesses the potential concordance of a strategic taboo with an organization's overall philosophy and purpose, instrumentalizing assesses such concordance with respect to what actors deem to be an organization's priorities and goals. Finally, normalizing explores concordance with respect to compatibility and fit with the organization's practices. We suggest that assessing concordance of a strategic taboo with identity elements consists in reinterpreting collective identity beliefs in ways that make them consistent with what organizational actors deem the right course of action.

Before presenting the implications of the concept of strategic taboo as well as our typology of reinterpretation practices in confronting taboos in more detail, we first outline some specificities of the case as to point to some more general contingencies relevant for appreciating our contribution.

First, our analysis was based on a strategic agenda setting process in a not-for-profit, missiondriven organization. We chose the case for its theoretical relevance since we believe that demonstrating and tracking discordance in such contexts is more likely to occur since the collective organization identity beliefs are primarily rooted in a normative realm such as ensuring human rights, preserving the environment, or promoting a specific spiritual, religious approach for that matter.

However, and despite the efficacy of our case setting and adjacent contexts, we believe that the concept of strategic taboos and the typology of reinterpretation practices have broader relevance. For instance, firms often face strategic rigidities and therefore, deselect strategic options from their strategic agenda at the possible expense of their competitive position. For instance, the failed recognition of digital photography by companies such as Kodak and Polaroid indicates that their strategic actors might have seen but at some stage disqualified digital photography as a viable strategic option because of a perceived discordance between the option and organizational identity beliefs (Tripsas and Gavetti, 2000). Also, when Microsoft's overall strategic aspiration was to "dominate the desktop" by selling operating systems and office applications in the 1990s, they 
were certainly aware of the Internet, but had not yet appreciated the relevance of a Web browser for their business until mid-1995 (Gates, 1995). In this case and while this strategic option was available in principle, it was initially deselected as it was not in concordance with the organizational identity belief of their raison d'être lying in the dominance of the desktop. So we note in passing that catching up on an initial strategic taboo might be costly.

A second contingency concerns the context specificity of organizational identity beliefs. While these differ substantively across organizations, we suggest that the three broad categories for an organization's key identity elements are valid nevertheless - and hence, the corresponding reinterpretation practice. Contextualizing a strategic taboo within an organization's overall philosophy and purpose, instrumentalizing the strategic taboos in terms of an organization's priorities, and normalizing the strategic taboo in assessing them against regular organizational practice are likely to take similar form in contexts akin to our context of study.

Third, our study operated on a set of explicit and discussable strategic options and our typology hinges on the premise that strategic taboos are open for debate and exploration. However, we are well aware that there are also "silent," implicit strategic taboos that are "silently" deselected without any prior consultation or concordance assessment. In settings where normative aspects such as a professional code or a belief system are tacit, merely implicit in nature, evaluating the tabooed options explicitly is challenging, and assessing them against a given set of organizational identity elements will be hard to enact. Consequently, an explicitly codified set (or sufficiently specified proxy) of organizational identity beliefs facilitates the process of confronting strategic taboos.

Against the backdrop of these qualified contingencies, we discuss the implications of our intended contributions for three main "audiences" as well as the limitations of our study.

\section{Implications for theory}

Our study stands to make several contributions. First, we offer the concept of strategic taboo, conceptualize confronting strategic taboos as consisting in a reinterpretation of organizational identity beliefs and its key elements, and develop a corresponding typology of practices of reinterpretation. So far, organizational identity has been viewed as shaping and filtering which issues are identified, included in the strategic agenda, and associated with organizational responses (Bansal, 2003; Dutton and Dukerich, 1991; Gioia and Thomas, 1996). Since a strategic option's concordance with organizational identity beliefs is likely to increase its chance of inclusion in a strategic agenda (Bansal, 2003; Dutton, 1997; Milliken, 1990), we sought to explore how strategic actors confront initially disqualified options. In defining a strategic taboo as an initially disqualified strategic option deemed inconsistent with organizational identity beliefs, we provide the field of strategic agenda setting with a concept and terminology to explore normatively and identity-based biases in strategic actors in a more systematic and precise manner. The concept of strategic taboo along with the typology of reinterpretation practices provides a more precise terminology and framework of why and how a strategic agenda might become unnecessarily restricted to a limited pool of strategic options (Dutton, 1986; Dutton and Penner, 1993). If we are to explain a foreshortened strategic agenda using the strategic taboo framework, we might suggest that overall a strategic option is deselected or ignored for the strategic agenda if it is not deemed in concordance with key elements of organizational identity beliefs. Furthermore - and beyond the scope of this article-a future, more prescriptively oriented study might explore the boundary conditions for "successful" reinterpretation practices.

The concept of strategic taboo also informs scholars concerned with strategic inertia (Hannan and Freeman, 1984; Hodgkinson and Wright, 2002) as well as studies on strategic myopia, whereby organizations are at risk of neglecting certain, disqualified but turned-out-to-be-promising 
opportunities outside what they consider their organizational identity (Levinthal and March, 1993; Tripsas and Gavetti, 2000). In particular, the concept of strategic taboo and the three practices of reinterpretation emphasize the relevance of organizational identity beliefs and in this supplement the managerial, emotional, and cognitive explanations for judgment (Hodgkinson and Wright, 2002). In our article, we demonstrate that strategic taboos are indeed contentious and are likely candidates for deselection; nevertheless, they may also be proactively evaluated for their concordance with purpose, priorities, and practices and can be subsequently integrated as viable strategic agenda items.

The concept of strategic taboo and the typology of practices of reinterpreting organizational identity beliefs have implications for the adjacent debate on effective strategic change in general (Greenwood and Hinings, 1996; Hannan and Freeman, 1984), and to those studies advocating the need to balance change with stability (Leana and Barry, 2000) in particular.

Interestingly, we believe that somewhat paradoxical strategic taboos can have a stabilizing function for an organization. Empirically, we studied a mission-driven organization which relies upon a specific set of (supposedly "eternal") religious, moral, and social norms that have stabilized this organization over several centuries (McDonald, 2007). Subjects, actions, and strategic options deemed as violating these sustained norms will very likely have been willfully silenced in the past (Shoemaker and Tetlock, 2012) since these norms offer a necessary constancy of tested and validated practices to members that in turn allow for a sustained development.

In LCG, we observed this affirmative effect of the taboos in the reinterpretation process as neither the practices nor their consequences did fundamentally shift, change, or even challenge LCG's organizational identity beliefs. Rather, and as the term "reinterpretation" suggests, a shared set of identity elements was mobilized in assessing the concordance of a taboo with organizational identity beliefs. Furthermore, and as stated above, strategic actors mobilized and drew on the same identity elements in their reinterpretation practices. Yet, and although their interpretations might have advocated concordance or discordance, the fact that the actors draw on the same identity elements revealed a higher-level agreement on these categories as a joint point of reference or interpretive repertoire.

Organizational identity elements were not presented as radically new or in need of fundamental overhaul but rather mobilized in "a rediscovery (re-focusing on) of values and attitudes that were already part of the collective heritage of the organization" (Gioia et al., 2013: 144). Hence, and while strategic taboos can constitute a threat to identity beliefs, the actor's drawing on a same interpretive repertoire has a stabilizing effect in the end. This finding resonates with Elsbach and Kramer's (1996) observation that identity threats are coped with by affirming positive, core identity elements. Furthermore, it finds further support by social identity scholars. Ellemers et al. (2002), for example, suggest that in a configuration whereby an identity threat-here in the form of a strategic taboo - is directed to a highly committed group, the group's likely response is affirming the initial group identity. In our case, and despite differing in their interpretations, the interpretive repertoire in terms of the key identity elements that strategic actors mobilize in the three reinterpretation practices remained consistent between advocates and skeptics alike.

The concept of strategic taboo and the typology of reinterpretation practices furthermore inform the debate on the adjacent but distinct construct of strategic blind spots (Geiger and Antonacopoulou, 2009; Ng et al., 2009; Zajac and Bazerman, 1991). To avoid confusion between the concepts, even though taboos and blind spots have been used as synonyms, we wish to stress the conceptual difference. Typically, a strategic taboo refers to a strategic option that is known by strategic actorsand then disqualified from the pool of strategic options. In contrast, a strategic blind spot refers to a strategic option that has not (yet) been recognized as such. If recognized, such former strategic 
blind spots can still be deemed a strategic taboo if assessed as lacking concordance with collective organizational identity beliefs.

Our typology also informs the practice-based view of strategy (e.g. Golsorkhi et al., 2010; Jarzabkowski et al., 2007; Vaara and Whittington, 2012) in which the process of strategic change in general and of resistance to imposed strategies in particular have received some scholarly attention. In a recent review of the field, Golsorkhi et al. (2010) called for more studies to explore how strategic actors and organizational members cope with (and even resist) certain aspects of strategy formation. Our study is an exemplar of a study that explores how organizational actors, in our case the strategic actors participating in the strategy process of LCG, confront strategic taboos. Furthermore, the concept of strategic taboo itself can also be mobilized to understand resistance as a plausible and subjectively legitimate reaction to certain strategic suggestions. In our case study, acknowledging and problematizing certain strategic options as inconsistent with the Lutheran ethos can be reframed as a form of open resistance. Despite the overall outcome of the empirical process, our analysis also demonstrated how each reinterpretation practice was mobilized by both advocates for or against concordance. We suggest that the notion of a strategic taboo informs a more analytical term and a potentially less moralizing perspective on strategic resistance. Our study extends current understanding of reactions to imposed strategies by showing that both the practices of reinterpretation and the decision for inclusion mark opportunities for open or hidden resistance, which is consequential for an organization's strategic agenda and, subsequently, the magnitude of change. Furthermore, our study answers recent calls for studies on strategy work in new empirical domains (Vaara and Whittington, 2012). By examining the processes of strategy formation in the Lutheran church, we explore a mission-driven organization characterized by an explicitly stated, codified frame of reference that in turn allowed for a more transparent evaluation of initially disqualified strategic options.

Finally, we inform research on the relationship between strategy and identity. Organizational identity has been proposed as a pivotal resource in providing direction to strategy formation (Corley and Gioia, 2004; Gioia and Thomas, 1996; Grant, 1991) or as a source for competitive advantage (Fiol, 2001). From a resource-based perspective, Grant (1991), for instance, suggests that any strategy formation requires a specification of an organization's identity to provide the very basis for its raison d'être and in this to offer guidance to any further strategy formation. Fiol (2001) argues that organizations able to adjust or even destroy their identities in line with external changes are more likely to attain transitional competitive advantage. In our study, organizational members initially conceived of the strategic taboo issues as a threat to what they believed the organization stands and stood for. As the strategic taboo was confronted by different practices of reinterpretation, we observe that strategy formation and organizational identity work are strongly related.

When assessing concordance of a strategic option with organizational identity beliefs, organizational members do not only talk "strategy" but rather, use the nexus between strategy and identity for reinterpretation of their identity beliefs (Ravasi and Phillips, 2011). Particularly with respect to the practice of contextualizing, organizational actors assess concordance of a strategic option and the organization's philosophy and purpose. Thus, what actors deem core attributes in terms of the central, distinctive, and enduring aspects of an organization's identity will indeed inform and influence the judgment by strategic actors when identifying strategic options for the agenda (Bartunek, 1984; Dutton and Penner, 1993). The notion of strategic taboo provides a construct to theorize a potential discordance between an organization's identity beliefs, on the one hand, and its strategic agenda for fundamental change, on the other. 


\section{Limitations and future research}

Our study is also subject to the following limitations. First, a single-case study comes with limitations for generalizability, and hence our claim to a moderate level of generalization from our case into the typology (Payne and Williams, 2005). Also, our data set unfortunately did not cover the initial phase of drafting and authoring the strategy white paper - that contained the two strategic options deemed out of bounds subsequently by many strategic actors in LCG. Furthermore, choosing a religious organization also limits the generalizability of our findings - although we believe that our findings have some direct resonance for mission-driven or pluralistic settings (Denis et al., 2007). Our choice of a mission-driven organization comes with the potential oversampling into the normative or moral realm, that is, less morally or spiritually oriented organizations might identify other types of taboos and might emphasize or prefer one reinterpretation practice over the others. The relationship between the three practices, their efficacy, and boundary conditions provide ample opportunities for further nuancing the process of confronting strategic taboos in organizations.

Furthermore, few organizations will actually have their norms, values, and beliefs as comprehensively codified and understood by their organizational members. Also, LCG's strategy process resulted in the organization accepting the initially disqualified strategic option into its strategic agenda. We anticipate this to be the exception to the rule. Finally, and while our data set is rich in terms of the strategy process, we have not covered the consequence of how strategic actors confronted the taboos for the overall strategic change process.

In turn, these limitations also provide useful guidance for a future research agenda on strategic taboos as well as the process and practices of confronting strategic taboos. A multi-case, comparative study design tracking how strategic actors confront taboos in different empirical contexts will allow scholars to elaborate on and, if need be, to refine, our proposed typology. Such studies will be in a position to compare and contrast the nature of strategic taboos and how actors confront them in more detail-ideally resulting in a process model in this respect. On a related note, future studies should explore whether, if at all, strategic taboos can be differentiated in terms of the magnitude of a taboo.

As initiator of the LCG and a change agent in his own right, Martin Luther was brave enough to break taboos in his time. May we conclude our article with a reminder attributed to Martin Luther: "You are not only responsible for what you say, but also for what you do not say."

\section{Funding}

Claus Jacobs gratefully acknowledges Swiss National Science Foundation Grant No. P00P1_139199.

\section{References}

Agarwal, R. and Helfat, C. E. (2009) "Strategic Renewal of Organizations," Organization Science 20: 281-93.

Albert, S. and Whetten, D. A. (1985) "Organizational Identity," Research in Organizational Behavior 7: 263-95.

Argyris, C. (1980) "Making the Undiscussable and Its Undiscussability Discussable," Public Administration Review 40(3): 205-13.

Ashford, S., Rothbard, N., Piderit, S. and Dutton, J. (1998) "Out on a Limb: The Role of Context and Impression Management in Selling Gender-Equity Issues," Administrative Science Quarterly 43(1): 23-57.

Bansal, P. (2003) "From Issues to Actions: The Importance of Individual Concerns and Organizational Values in Responding to Natural Environmental Issues," Organization Science 14(5): 510-27.

Barr, P. S., Stimpert, J. L. and Huff, A. S. (1992) "Cognitive Change, Strategic Action, and Organizational Renewal," Strategic Management Journal 13: 15-36. 
Bartunek, J. M. (1984) "Changing Interpretive Schemes and Organizational Restructuring: The Example of a Religious Order," Administrative Science Quarterly 29(3): 355-72.

Clark, S. M., Gioia, D. A., Ketchen, D. J. Jr. and Thomas, J. B. (2010) "Transitional Identity as a Facilitator of Organizational Identity Change during a Merger," Administrative Science Quarterly 55(3): 397-438.

Corley, K. G. and Gioia, D. A. (2004) "Identity Ambiguity and Change in the Wake of a Corporate Spin-Off," Administrative Science Quarterly 49(2): 173-208.

Corley, K. G., Harquail, C. V., Pratt, M. G., Glynn, M. A., Fiol, C. M. and Hatch, M. J. (2006) "Guiding Organizational Identity Through Aged Adolescence," Journal of Management Inquiry 15(2): 85-99.

Denis, J.-L., Langley, A. and Rouleau, L. (2007) "Strategizing in Pluralistic Contexts: Rethinking Theoretical Frames," Human Relations 60: 179-215.

Dutton, J. (1986) "Understanding Strategic Agenda Building and its Implications for Managing Change," Scandinavian Journal of Management Studies 3(10): 3-24.

Dutton, J. (1997) "Strategic Agenda Building in Organizations," in Z. Shapira (ed.) Organizational Decision Making, pp. 81-105. Cambridge, MA: Cambridge University Press.

Dutton, J. and Ashford, S. (1993) "Selling Issues to Top Management," Academy of Management Review 18(3): 397-428.

Dutton, J. and Dukerich, J. (1991) "Keeping an Eye on the Mirror: Image and Identity in Organizational Adaptation," Academy of Management Journal 34(3): 517-54.

Dutton, J. and Jackson, S. (1987) "Categorizing Strategic Issues: Links to Organizational Action," Academy of Management Review 12(1): 76-81.

Dutton, J. and Penner, W. (1993) "The Importance of Organizational Identity for Strategic Agenda Building," in J. Hendry and J. Newton (eds) Strategic Thinking: Leadership and the Management of Change, pp. 89-113. New York: John Wiley \& Sons, Strategic Management Society.

Dutton, J., Ashford, S., Lawrence, K. and Miner-Rubino, K. (2002) "Red Light, Green Light: Making Sense of the Organizational Context for Issue Selling," Organization Science 13(4): 355-69.

Ellemers, N., Spears, R. and Doosje, B. (2002) "Self and Social Identity," Annual Review of Psychology 53: 161-86.

Elsbach, K. D. and Kramer, R. M. (1996) "Members' Responses to Organizational Identity Threats: Encountering and Countering the Business Week Rankings," Administrative Science Quarterly 41(3): 442-76.

Fiol, S. M. (2001) "Revisiting an Identity-based View of Sustainable Competitive Advantage," Journal of Management 27(6): 691-9.

Floyd, S. W. and Lane, P. J. (2000) "Strategizing Throughout the Organization: Managing Role Conflict in Strategic Renewal," Academy of Management Review 25(1): 154-77.

Gates, B., Myhrvold, N. and Rinearson, P. (1995) The Road Ahead. New York, NY: Penguin.

Geiger, D. and Antonacopoulou, E. (2009) "Narratives and Organizational Dynamics: Exploring Blind Spots and Organizational Inertia," Journal of Applied Behavioral Science 45(3): 411-36.

Gioia, D. A. and Patvardhan, S. (2012) "Identity as Process and Flow," in S. Maguire, M. Schultz, A. Langley and H. Tsoukas (eds) Constructing Identity in and Around Organizations, vol. 3, pp. 50-62. Oxford: Oxford University Press.

Gioia, D. A. and Thomas, J. B. (1996) "Identity, Image, and Issue Interpretation: Sensemaking during Strategic Change in Academia," Administrative Science Quarterly 41: 370-403.

Gioia, D. A., Patvardhan, S. D., Hamilton, A. L. and Corley, K. G. (2013) "Organizational Identity Formation and Change," Academy of Management Annals 7(1): 123-93.

Gioia, D. A., Price, K. N., Hamilton, A. L. and Thomas, J. B. (2010) "Forging an Identity: An InsiderOutsider Study of Processes Involved in the Formation of Organizational Identity," Administrative Science Quarterly 55(1): 1-46.

Gioia, D. A., Schultz, M. and Corley, K. G. (2000) “Organizational Identity, Image, and Adaptive Instability," Academy of Management Review 25(1): 63-81.

Glaser, B. and Strauss, A. (1967) The Discovery of Grounded Theory: Strategies of Qualitative Research. London: Wiedenfeld and Nicholson. 
Golden-Biddle, K. and Rao, R. (1997) "Breaches in the Boardroom: Organizational Identity and Conflicts of Commitment in a Non Profit Organization," Organization Science 8: 593-611.

Golsorkhi, D., Rouleau, L., Seidl, D. and Vaara, E. (2010) "Introduction: What is Strategy-as-Practice?," in D. Golsorkhi, L. Rouleau, D. Seidl and E. Vaara (eds) Cambridge Handbook of Strategy as Practice, pp. 1-18. Cambridge, MA: Cambridge University Press.

Grant, R. M. (1991) "The Resource-Based Theory of Competitive Advantage: Implications for Strategy Formulation," California Management Review 33: 114-35.

Greenwood, R. and Hinings, C. R. (1996) "Understanding Radical Organizational Change: Bringing Together the Old and the New Institutionalism," Academy of Management Review 21(4): 1022-54.

Gustafson, L. T. and Reger, R. K. (1995) "Using Organizational Identity to Achieve Stability and Change in High Velocity Environments," Academy of Management Best Papers Proceedings: 464-8. Available at: http://proceedings.aom.org/content/1995/1/464.full.pdf

Hamel, G. and Prahalad, C. K. (1994) "Competing for the Future," Harvard Business Review 72(4): 122-8.

Hamilton, A. L. and Gioia, D. A. (2010) "Organizational Identity and Strategic Decision Making" in P. C. Nutt and D. C. Wilson (eds) Handbook of Decision Making, pp. 139-52. Chichester: John Wiley \& Sons.

Hannan, M. T. and Freeman, J. (1984) "Structural Inertia and Organizational Change," American Sociological Review 49(2): 149-64.

Hodgkinson, G. and Wright, G. (2002) "Confronting Strategic Inertia in a Top Management Team: Learning from Failure," Organization Studies 23(6): 949-77.

Huy, Q. N. (2011) "How Middle Managers' Group-Focus Emotions and Social Identities Influence Strategy Implementation," Strategic Management Journal 32(13): 1387-410.

Jarzabkowski, P. and Fenton, E. (2006) "Strategizing and Organizing in Pluralistic Contexts," Long Range Planning 39(6): 631-48.

Jarzabkowski, P., Balogun, J. and Seidl, D. (2007) "Strategizing: The Challenges of a Practice Perspective," Human Relations 60(1): 5-27.

Jeavons, T. H. (1992) "When the Management is the Message: Relating Values to Management Practice in Nonprofit Organizations," Nonprofit Management and Leadership 2(4): 403-17.

Ketokivi, M. and Mantere, S. (2010) "Two Strategies for Inductive Reasoning in Organizational Research," Academy of Management Review 35(2): 315-33.

Kumar, N., Stern, L. W. and Anderson, J. C. (1993) "Conducting Interorganizational Research Using Key Informants," Academy of Management Journal 36(6): 1633-51.

Langley, A. (1999) "Strategies for Theorizing from Process Data," Academy of Management Review 24(4): 691-710.

Leana, C. R. and Barry, B. (2000) "Stability and Change as Simultaneous Experiences in Organizational Life," Academy of Management Review 25(4): 753-80.

Levinthal, D. A. and March, J. G. (1993) "The Myopia of Learning," Strategic Management Journal 14: 95-112.

Livengood, R. S. and Reger, R. K. (2010) "That's Our Turf! Identity Domains and Competitive Dynamics," Academy of Management Review 35: 48-66.

McDonald, R. E. (2007) "An Investigation of Innovation in Nonprofit Organizations: The Role of Organizational Mission," Nonprofit and Voluntary Sector Quarterly 36(2): 256-81.

Margolis, S. L. and Hansen, C. D. (2002) "A Model for Organizational Identity: Exploring the Path to Sustainability during Change," Human Resource Development Review 1(3): 277-303.

Markides, C. (1997) "Strategic Innovation," Sloan Management Review 38(3): 9-23.

Marshall, D. A. (2010) “Temptation, Tradition, and Taboo: A Theory of Sacralization," Sociological Theory 28: 64-90.

Martin, J. (1990) "Deconstructing Organizational Taboos: The Suppression of Gender Conflict in Organizations," Organization Science 1(4): 339-59.

Miles, M. B. and Huberman, A. M. (1994) Qualitative Data Analysis: An Expanded Sourcebook, 2nd edn. Thousand Oaks, CA: Sage.

Miller, K. D. (2002) "Competitive Strategies of Religious Organizations," Strategic Management Journal 23: $435-56$. 
Milliken, F. J. (1990) "Perceiving and Interpreting Environmental Change: An Examination of College Administrators' Interpretation of Changing Demographics," Academy of Management Journal 33: 42-63.

Minkoff, D. C. and Powell, W. W. (2006) "Nonprofit Mission: Constancy, Responsiveness, or Deflection?," in W. W. Powell and R. Steinberg (eds) The Non-Profit Sector, 2nd edn, pp. 591-611. New Haven, CT: Yale University Press.

Nag, R., Corley, K. G. and Gioia, D. A. (2007) “The Intersection of Organizational Identity, Knowledge, and Practice: Attempting Strategic Change Via Knowledge Grafting," Academy of Management Journal 50(4): 821-47.

Ng, D., Westgren, R. and Sonka, S. (2009) "Competitive Blind Spots in an Institutional Field," Strategic Management Journal 30(4): 349-69.

Patton, M. Q. (2002) Qualitative Evaluation and Research Methods, 3rd edn. Thousand Oaks, CA: Sage.

Payne, G. and Williams, M. (2005) "Generalization in Qualitative Research," Sociology 39(2): 295-314.

Plambeck, N. and Weber, K. (2009) "When the Glass is Half Full and Half Empty: CEO's Ambivalent Interpretations of Strategic Issues," Strategic Management Journal 31: 689-710.

Ravasi, D. and Phillips, N. (2011) "Strategies of Alignment: Organizational Identity Management and Strategic Change at Bang \& Olufsen," Strategic Organization 9(2): 103-35.

Ravasi, D. and Schultz, M. (2006) "Responding to Organizational Identity Threats: Exploring the Role of Organizational Culture," Academy of Management Journal 49: 433-58.

Reger, R. K., Gustafson, L. T., Demarie, S. M. and Mullane, J. V. (1994) "Reframing the Organization: Why Implementing Total Quality is Easier Said than Done," Academy of Management Review 19(3): 565-84.

Schoemaker, P. J. and Tetlock, P. E. (2012) "Taboo Scenarios: How to Think About the Unthinkable," California Management Review 54(2): 5-24.

Schwenk, C. R. (1988) "The Cognitive Perspective on Strategic Decision Making," Journal of Management Studies 25: 41-55.

Sharma, S. (2000) "Managerial Interpretations and Organizational Context as Predictors of Corporate Choice of Environmental Strategy," Academy of Management Journal 43(4): 681-97.

Slok, C. (2009) "Disorganization as Religion: Managing the Danish National Evangelical Lutheran Church," Cybernetics and Human Knowing 16(1-2): 51-64.

Sonenshein, S. (2007) "The Role of Construction, Intuition, and Justification in Responding to Ethical Issues at Work: The Sensemaking-Intuition Model," Academy of Management Review 32(4): 1022-40.

Sonenshein, S., DeCelles, K. A. and Dutton, J. E. (2014) "It's not Easy Being Green: The Role of SelfEvaluations in Explaining Support of Environmental Issues," Academy of Management Journal 57: 7-37.

Stake, R. E. (2005) "Qualitative Case Studies," in N. K. Denzin and Y. S. Lincoln (eds) The Sage Handbook of Qualitative Research, 3rd edn, pp. 443-66. Thousand Oaks, CA: Sage.

Steiner, F. (1956) Taboo. London: Cohen \& West.

Strauss, A. and Corbin, J. (1990) Basics of Qualitative Research: Grounded Theory Procedures and Techniques. Thousand Oaks, CA: Sage.

Tetlock, P. E. (2003) "Thinking the Unthinkable: Sacred Values and Taboo Cognitions," Trends in Cognitive Sciences 7(7): 320-4.

Thomas, J. B. and McDaniel, R. (1990) "Interpreting Strategic Issues: Effects of Strategy and the Information Processing structure of Top Management Team," Academy of Management Journal 33: 286-306.

Thomas, J. B., Clark, S. M. and Gioia, D. A. (1993) "Strategic Sensemaking and Organizational Performance: Linkages Among Scanning, Interpretation, Action, and Outcomes," Academy of Management Journal 36(2): 239-70.

Tripsas, M. and Gavetti, G. (2000) "Capabilities, Cognition, and Inertia: Evidence from Digital Imaging," Strategic Management Journal 21(10-11): 1147-61.

Tushman, M. and Romanelli, E. (1985) "Organizational Evolution: A Metamorphosis Model of Convergence and Reorientation," in L. L. Cummings and B. M. Staw (eds) Research in Organizational Behavior, vol. 7, pp. 171-222. Greenwich, CT: JAI Press.

Vaara, E. and Whittington, R. (2012) "Strategy-as-Practice: Taking Social Practices Seriously," Academy of Management Annals 6(1): 285-336. 
Webster, H. (1942) Taboo: A Sociological Study. Stanford, CA: Stanford University Press.

Whetten, D. A. and Godfrey, P. C. (1998) Identity in Organizations: Building Theory Through Conversations. Thousand Oaks, CA: Sage.

Yin, R. K. (2009) Case Study Research: Design and Methods, 4th edn. Thousand Oaks, CA: Sage.

Zajac, E. J. and Bazerman, M. H. (1991) "Blind Spots in Industry and Competitor Analysis: Implications of Interfirm (Mis)Perceptions for Strategic Decisions," Academy of Management Review 16(1): 37-56.

Zuesse, E. M. (1974) "Taboo and the Divine Order," Journal of the American Academy of Religion 42(3): 482-504.

\section{Author biographies}

Christina Hoon received her PhD from the Leibniz University of Hannover. She is a post-doctoral researcher at the Institute of Human Resource Management, Leibniz University of Hannover. Her research interests focus on organizational and strategic change in pluralistic settings with an emphasis on strategy-as-practice, organizational sensemaking, dynamic capabilities, and qualitative research, in particular case study methods and qualitative meta-synthesis. Her publications include articles in Human Relations, Research Methodology in Strategy and Management, Organizational Research Methods, and the British Journal of Management among others.

Claus D Jacobs is Professor of Strategic Management and Organization at Berne School of Management, Institute for Corporate Development, UAS Berne. He holds a PhD from University of Dublin, Trinity College, as well as a venia legendi from University of St. Gallen. From 2008 to 2013 he was Swiss National Science Foundation Professor at University of St Gallen. Since 2014, he is Associate Fellow of University of Oxford, Said Business School, and a Visiting Professor of University of St Gallen. He is member of the editorial boards of Journal of Management Studies and Scandinavian Journal of Management as well as Executive Committee Member of the Strategizing Activities and Practices Division at the Academy of Management. His research has been published in Organization Studies, Journal of Management Studies, MIT Sloan Management Review, Human Relations, Journal of Applied Behavioral Science, and Journal of Organizational Change Management among others. Recently, he published with Loizos Heracleous (Warwick Business School) "Crafting Strategy_Embodied Metaphors in Practice" at Cambridge University Press (Paperback 2013). 